\title{
ANALISIS STRUKTUR KOMUNITAS MAKROALGA EKONOMIS PENTING DI PERAIRAN INTERTIDAL MANOKWARI, PAPUA BARAT
}

\author{
STRUCTURE ANALYSIS OF MAKROALGAE COMMUNITY AT INTERTIDAL \\ COASTAL AREA IN MANOKWARI, WEST PAPUA
}

\author{
Hendrik Victor Ayhuan ${ }^{1}$, Neviaty Putri Zamani ${ }^{2}$, Dedi Soedharma ${ }^{2}$ \\ ${ }^{1}$ Program Studi Ilmu Kelautan, Sekolah Pascasarjana \\ ${ }^{2}$ Departemen Ilmu dan Teknologi Kelautan, \\ Fakultas Perikanan dan Ilmu Kelautan, Institut Pertanian Bogor \\ Korespondensi: hendrikayhuan@ymail.com
}

\begin{abstract}
Macroalga in Manokwari area has higher species biodiversity, however this organism is very risk to environment kondition change either nature or anthropogenic pressure. This study aimed to composition species of algae (clasification and identification) and community assemblage analysis of macroalgae species surrounding Manokwari coastal area. Collecting data was done during east season period (from June 2014 to September 2014) from two different main coastal areas, mainland and outland coastal area. Twenty eight macroalga species were identified and consisted taxonomically of three divisions, three classes, eleven orders, sixteen families, and nineteen genus. Three divisions of macroalga species were green alga (Chlorophyta), red alga (Rhodophyta), and brown alga (Phaeophyta), which each division comprised with 14 species, 8 species, and 6 species respectively. Total of density average of macroalga species in outland was higher than that of in mainland. Structure analysis of macroalga community in outland areas (Mansinam and Lemon) had higher biodiversity index than that of in mainland areas (Rendani, Pasir Putih, and Arfai). Evenness index in both mainland and outland areas were closed to 1, which meant individual of macroalga from each species distributed uniformly and there was no dominant macroalga species. While dominancy index in either mainland or outland reached closely to zero, which meant macroalga community were stable.
\end{abstract}

Keyword: classification, community assemblage of analysis, macroalga species, Manokwari

\begin{abstract}
ABSTRAK
Makroalga di daerah Manokwari memiliki keanekaragaman spesis yang tinggi, namun organisme ini sangat rentan terhadap perubahan kondisi lingkungan baik alami maupun tekanan antropogenik. Tujuan penelitian ini adalah mengkaji komposisi spesies makroalga (klasifikasi dan identifikasi) dan menganalisis struktur komunitas makroalga di perairan intertidal Manokwari Papua Barat. Penelitian pengambilan data di lapangan pada bulan Juni 2014 sampai September 2014 (periode musim timur) pada 2 daerah penelitian yaitu mainland dan outland. Komposisi spesies makroalga ditemukan 28 spesies yang diklasifikasikan ke dalam 3 divisi, 3 kelas, 11 ordo, 16 famili, dan 19 genus. Spesies alga yang di temukan tersebut dikelompokkan dalam 3 divisi utama yaitu alga hijau (Chlorophyta) 14 spesies, alga merah (Rhodophyta) 8 spesies dan alga coklat (Phaeophyta) 6 spesies. Total rata-rata kepadatan jenis makroalga daerah outland lebih tinggi dibandingkan dengan mainland. Analisis struktur komunitas makroalga daerah outland lokasi Mansinam dan Lemon memiliki indeks keanekaragaman lebih tinggi di bandingkan dengan daerah mainland lokasi Rendani, Pasir Putih dan Arfai. Indeks keseragaman pada 5 lokasi penelitian daerah mainland dan outland mendekati 1 dimana populasi individu makroalga tiap jenis menyebar merata dan tidak ada makroalga yang dominan, sedangkan indeks dominansi mendekati nol dimana komunitas makroalga penyusunnya berada dalam keadaan stabil.
\end{abstract}

Kata kunci: analisis struktur komunitas, klasifikasi, Manokwari, spesies makroalga 


\section{PENDAHULUAN}

Makroalga merupakan sumberdaya hayati yang sangat potensial untuk dikembangkan dan tersebar di daerah pesisir intertidal. Makroalga atau "seaweed" memiliki peranan penting baik dari segi biologis, ekologis maupun ekonomis yang dapat mempertahankan keanekaragaman sumberdaya hayati laut. Makroalga di daerah Manokwari Papua Barat memiliki keanekaragaman spesies (biodiversity) yang tinggi, namun organisme ini sangat rentan terhadap perubahan kondisi lingkungan atau tekanan ekologis baik secara alami seperti faktor angin, gelombang, arus dan musim menjadi faktor pemicu perubahan habitat makroalga (Papalia et al. 2013). Tekanan antropogenik seperti limbah domestik, buangan sampah padat, aktivitas masyarakat perkotaan, frekuensi transportasi kapal di daerah Teluk, kegiatan pembangunan tata kota dan aktivitas masyarakat di perairan cenderung mempengaruhi pertumbuhan perkembangan keanekaragaman makroalga (Langoy et al. 2011; Litaay 2014). Kondisi lingkungan seperti faktor substrat, gerakan air, suhu, salinitas, pasang-surut, cahaya, $\mathrm{pH}$, nutrien dan kualitas perairan harus dijaga supaya tidak mengalami degradasi penyusutan dan penurunan kualitas yang akan menimbulkan kerusakan bahkan kepunahan jenis makroalga (Lobban \& Horrison 1997).

Manokwari merupakan daerah pesisir pantai yang memiliki potensi sumberdaya alam yang cukup melimpah termasuk alga tetapi dalam hal penelitian serta informasi ilmiah yang diperoleh tentang sumberdaya alam ini masih kurang, untuk itu diperlukan penelitian tentang komposisi makroalga dengan menginventarisasi dan mengidentifikasi pengenalan jenisjenis makroalga ekonomis penting, serta menganalisis keadaan struktur komunitas makroalga perairan Manokwari hal ini menarik untuk dilakukan karena hasil penelitian dapat memberikan informasi data ilmiah kepada pemerintah daerah kabupaten Manokwari provinsi Papua Barat guna pengembangan, pemanfaatan dan pengelolaan berkelanjutan sumberdaya makroalga dalam pengambilan kebijakan strategis yang dapat dimanfaatkan oleh masyarakat lokal dalam kegiatan budidaya untuk peningkatan taraf hidup ekonomi mereka.

\section{METODE PENELITIAN}

Penelitian pengambilan data di lapangan dilaksanakan 4 bulan dari bulan Juni 2014 sampai bulan September 2014 (Periode Musim Timur) di 5 stasiun penelitian yaitu : Pantai Arfai (Stasiun 1), Pantai Rendani (Stasiun 2), Pantai Pasir Putih (Stasiun 3) merupakan Teluk Doreri bagian dalam (mainland) dan Pesisir Pulau Mansinam (Sasiun 4), Pesisir Pulau Lemon (Stasiun 5) merupakan Teluk Doreri bagian luar (outland). Posisi geografis lokasi pengambilan contoh ditentukan menggunakan Global Positioning System (GPS) kemudian diplotkan kedalam peta. Data peta penelitian berdasarkan pada citra Google Earth tahun 2014. Pengolahan peta menggunakan software ArcGis 10.0 dapat dilihat pada Gambar 1. Alat dan bahan yang digunakan dalam penelitian ini disajikan pada Tabel 1.

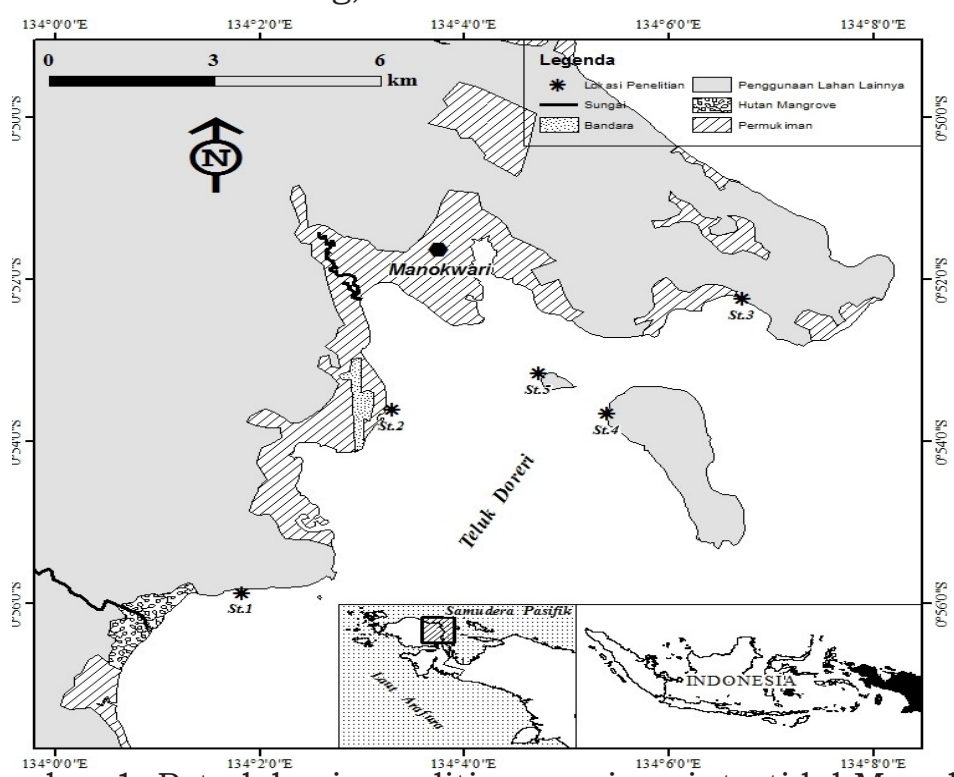

Gambar 1. Peta lokasi penelitian perairan intertidal Manokwari 
Tabel 1. Alat dan bahan yang digunakan dalam penelitian

\begin{tabular}{rllll}
\hline No & \multicolumn{1}{c}{ Parameter } & Satuan & \multicolumn{1}{c}{ Alat/Bahan } & \multicolumn{1}{c}{ Pengukuran } \\
\hline \multicolumn{1}{l}{ Fisika } & Suhu & ${ }^{\circ} \mathrm{C}$ & Termometer & In situ \\
2 & Kedalaman & $\mathrm{m}$ & Tongkat berskala & In situ \\
3 & Kecerahan & $\mathrm{m}$ & Secchi disk & In situ \\
4 & Kecepatan arus & $\mathrm{md}$ & Current meter & In situ \\
5 & Tekstur substrat & $\%$ & Ayakan bertingkat & Laboratorium \\
6 & Kekeruhan & NTU & Turbidity meter & Laboratorium \\
& Kimia & & & \\
7 & Salinitas & $\%$ & Hand refraktometer & In situ \\
8 & Derajat keasaman (pH) & - & pH meter & In situ \\
9 & Oksigen terlarut & $\mathrm{mg} / 1$ & DO meter & In situ \\
10 & Nitrat (NO3-N) & $\mathrm{mg} / 1$ & Spektrofotometer & Labolatorium \\
11 & Ortho-fosfat (PO4-P) & $\mathrm{mg} / 1$ & Spektrofotometer & Labolatorium \\
& Biologi & & & \\
12 & Komposisi jenis makroalga & Ind $/ \mathrm{m}^{2}$ & Kuadrat & In situ \\
13 & Kepadatan makroalga & Ind $/ \mathrm{m}^{2}$ & Kuadrat & In situ \\
14 & Penutupan makroalga & $\%$ & Kuadrat & In situ \\
& Data Pendukung & & & In situ \\
15 & Posisi lokasi sampling & Derajat $\left({ }^{\circ}\right)$ & GPS Garmin XL12 & Laboratorium \\
16 & Identifikasi makroalga & - & Buku Identifikasi & \\
\hline
\end{tabular}

\section{Metode pengambilan dan analisis sampel}

Metode pengambilan sampel menggunakan metode garis transek (line transect) dengan teknik sampling kuadran (English et al. 1997). Pengambilan sampel dilakukan pada 5 lokasi penelitian di mana penempatan transek dibagi menjadi 3 garis transek sepanjang $50 \mathrm{~m}$ yang di letakkan tegak lurus (vertikal) terhadap garis pantai dengan 5 kuadran (ukuran $1 \times 1 \mathrm{~m}^{2}$ ) jarak antar kuadran dalam satu garis transek $10 \mathrm{~m}$ serta jarak antar transek $50 \mathrm{~m}$. Setiap kuadran determinasi dan hitung jumlah individu setiap spesies makroalga. Sampel yang telah terkumpul di bawa ke laboratorium Perikanan dan Ilmu Kelautan FPIK Universitas Negeri Papua kemudian dikelompokkan ke dalam masing-masing divisi (Chlorophyta, Rhodophyta dan Phaeophyta) untuk proses identifikasi mengacu pada literatur menurut William \& Hunt (1979); Teo \& Wee (1983); Bold \& Wyne (1985); Chapman \& Chapman (1990); Lewmanomont \& Ogawa (1995); Atmadja et al. (1996); Silva et al. (1996); Calumpong \& Menez (1997); Trono (1997); Verbruggen et al.
(2005); Coppejans et al. (2009); Bhavanath et al. (2009); Verbruggen et al. (2009); Eem (2010); Krupek \& Branco (2012); Guiry \& Guiry (2014).

Sampel untuk analisis substrat dibawa ke laboratorium untuk proses identifikasi dengan cara dibersihkan dan dikeringkan dalam oven pada suhu $105^{\circ} \mathrm{C}$ selama 24 jam sampai berat konstan. Sedimen diayak berdasarkan ukuran mesh size ayakan (2 $\mathrm{mm}, 1 \mathrm{~mm}, 500 \mu \mathrm{m}, 250 \mu \mathrm{m}, 125 \mu \mathrm{m}, 63$ $\mu \mathrm{m}, 38 \mu \mathrm{m}$ ) masukkan kealat CISE (Siever shaker MOD) dengan power level $0.5 \mathrm{rpm}$ selama 10 menit.

Pengolahan contoh sedimen ini menggunakan metode kering (Eleftheriou \& McIntyre 2005). Hasil penyaringan berdasarkan mesh size ayakan (ayakan bertingkat) kemudian ditimbang dengan timbangan analitik dicatat hasilnya dalam tabel selanjutnya dihitung berat (gr) dan persen kumulatifnya, selanjutnya disesuaikan dengan nilai phi (Ø) menurut skala Wenworth. Sebaran butiran tekstur subsrat (\%) dan berat (gr) dapat diketahui berdasarkan hasil analisis ini. Analisis parameter fisik-kimia lingkungan proses 
pengukuran secara In situ di lapangan sedangkan untuk analisis nitrat (NO3-N) dan ortho-fosfat (PO4-P) menggunakan spektrofotometer dianalisis di laboratorium Produktivitas Lingkungan Perairan FPIK Institut Pertanian Bogor.

\section{Analisis data}

\section{Kepadatan jenis makroalga}

Kepadatan jenis makroalga yaitu jumlah individu makroalga (thallus) per satuan luas (Krebs 1989).

$$
D i=n i / A
$$

Dimana :

$$
\begin{aligned}
D i= & \text { Jumlah individu makroalga (thallus) } \\
& \text { ke }-\mathrm{i} \text { per satuan luas } \\
n i= & \text { Jumlah individu makroalga (thallus) } \\
& \text { ke }-\mathrm{i} \text { dalam transek kuadrat } \\
A= & \text { Luas transek kuadrat }
\end{aligned}
$$

\section{Keanekaragaman (H')}

Keanekaragaman adalah banyaknya jenis makroalga dan penyebaran jumlah individu makroalga dalam tiap jenisnya. Keanekaragaman jenis makroalga dihitung dengan Indeks Shannon (Ludwig \& Reynolds 1988).

$$
H^{\prime}=\sum_{i=1}^{s} p_{i} \ln p_{i}
$$

Dimana :

$H^{\prime} \quad=$ Indeks Keanekaragaman Shannon

$p_{i} \quad=$ Perbandingan antara jumlah individu spesies makroalga ke-i $\left(\mathrm{n}_{\mathrm{i}}\right)$ dengan jumlah total individu makroalga (N)

$s=$ Jumlah spesies makroalga ke-i

Kriteria penilaian berdasarkan keanekaragaman jenis ini adalah :

1. Jika $H^{\prime} \leq 1$, keanekaragaman rendah, penyebaran rendah, makroalga tiap jenis rendah dan kestabilan komunitas rendah.

2. Jika $1<\mathrm{H}^{\prime}<3$, keanekaragaman sedang, penyebaran sedang, makroalga tiap jenis sedang dan kestabilan komunitas sedang.

3. Jika $H^{\prime}>3$, keanekaragaman tinggi, penyebaran tinggi, makroalga tiap jenis tinggi dan kestabilan komunitas tinggi.

Keseragaman (E)
Keseragaman jenis merupakan komposisi individu makroalga tiap spesies yang terdapat dalam komunitas. Keseragaman jenis $(E)$ dihitung dengan membandingkan indeks keanekaragaman dengan nilai maksimumnya (Krebs 1989).

$$
E=\frac{H^{\prime}}{H_{\text {max }}^{\prime}}
$$

Dimana :

E $\quad=$ Indeks Keseragaman (berkisar antara $0-1)$

$H^{\prime} \quad=$ Indeks Keanekaragaman

$H_{\text {max }}^{\prime}=\ln \mathrm{s}(\log 2 \mathrm{~s})=$ Indeks keanekaragaman maksimum (dimana $\mathrm{s}=$ jumlah spesies makroalga).

Nilai keseragaman berkisar antara 0-1. Semakin kecil nilai tersebut (mendekati 0), maka semakin kecil keseragaman yang ada sebaliknya jika nilai keseragaman tinggi (mendekati 1), maka populasi individu makroalga menyebar merata dan tidak ada jenis makroalga tertentu yang dominan.

\section{Dominansi}

Indeks dominansi jenis digunakan menggambarkan jenis makroalga yang paling banyak di temukan dengan menghitung nilai dominansinya. Indeks dominansi diperoleh menurut indeks dominansi Simpson (Krebs 1989).

$$
C=\sum_{i=1}^{s}\left(\frac{n_{i}}{N}\right)^{2}=\sum_{i=1}^{s}\left(P_{i}\right)^{2}
$$

Dimana:

C = Indeks dominansi simpson

$n_{i} \quad=$ Jumlah individu makroalga jenis ke-i

$N=$ Jumlah total individu makroalga

Nilai indeks dominansi Simpson berkisar antara $0-1$, dengan kriteria :

1. $\mathrm{C}=\sim 0$, dalam komunitas tidak ada jenis makroalga yang dominan (melimpah) atau komunitas berada dalam keadaan stabil biasanya diikuti oleh nilai keseragaman yang besar.

2. $\mathrm{C}=\sim 1$, dalam komunitas ada dominansi dari satu jenis makroalga tertentu atau komunitas berada dalam keadaan tidak stabil biasanya diikuti oleh nilai indeks keseragaman yang kecil. 


\section{HASIL DAN PEMBAHASAN}

\section{Deskripsi lokasi penelitian}

Manokwari terletak di antara $132^{\circ} 35^{\prime}$ $134^{\circ} 45^{\prime} \mathrm{BT}$ dan $0^{\circ} 15^{\prime}-3^{\circ} 25^{\prime} \mathrm{LS}$, berada tepat di sebelah utara garis khatulistiwa dengan ketinggian $2.985 \mathrm{~m}$ di atas permukaan laut di wilayah provinsi Papua Barat. Posisi wilayah secara geografis sebelah utara berbatasan dengan Samudera Pasifik, selatan berbatasan dengan Kabupaten Teluk Wondama dan Kabupaten Teluk Bintuni, barat dengan Kabupaten Sorong Selatan dan timur dengan Kabupaten Biak Numfor (BPS 2014).

\section{Komposisi spesies makroalga}

Berdasarkan hasil penelitian pada kelima lokasi secara keseluruhan ditemukan 28 spesies makroalga yang di klasifikasikan ke dalam 3 divisi, 3 kelas, 11 ordo, 16 famili, dan 19 genus dengan komposisi dan jumlah spesisi Arfai 16 spesies, Rendani 14 spesies, Pasir putih 15 spesies, Pulau Mansinam
21 spesies dan Pulau Lemon 21 spesies. Penelitian ini menemukan 28 spesies makroalga, jumlah ini jauh lebih tinggi dari penelitian komunitas makroalga di perairan Teluk Ambon yang ditemukan 21 spesies (Litaay 2014), dan penelitian di Taman Wisata Alam Batuputih, kota Bitung spesies yang ditemukan berjumlah 18 spesies (Langoy et al. 2011). Tetapi penelitian ini lebih rendah dari jumlah spesies yang ditemukan oleh Papalia \& Arfah (2013) menemukkan 33 jenis di perairan Pulau Ambalau, Kabupaten Buru Selatan Ambon. Hasil penelitian menunjukkan jumlah spesies berdasarkan divisi pada 5 lokasi penelitian diperlihatkan pada Gambar 2.

Lokasi Arfai (stasiun 1) ditemukan 16 spesies yang dapat dilihat pada Tabel 2. Sedangkan lokasi Rendani (stasiun 2) ditemukan 14 spesies yang dapat dilihat pada Tabel 3. Lokasi Pasir Putih (stasiun 3) ditemukan 15 spesies, klasifikasinya dapat dilihat pada Tabel 4. Kemudian untuk lokasi pulau Mansinam (stasiun 4) ditemukan 21 spesies yang dapat dilihat pada Tabel 5 . Lokasi Pulau Lemon (stasiun 5) ditemukan 21 spesies, dapat dilihat pada Tabel 6.

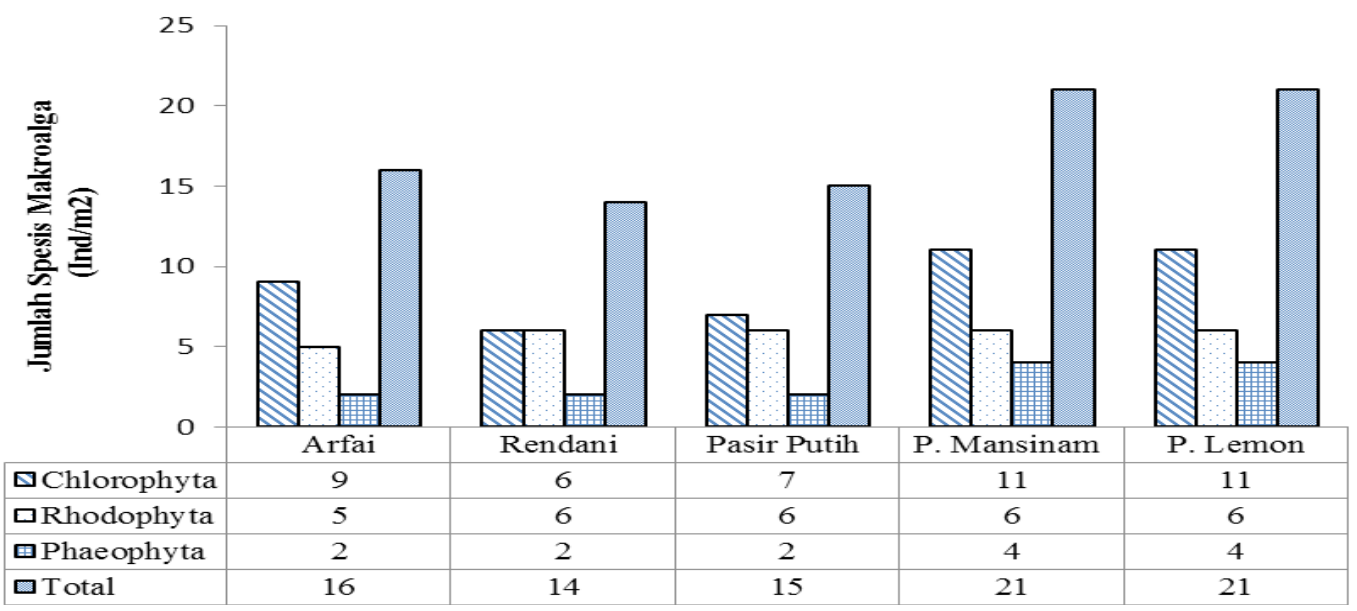

Gambar 2. Histogram jumlah spesies berdasarkan divisi yang ditemukan pada lima lokasi penelitian di perairan Manokwari 
Tabel 2. Klasifikasi makroalga yang ditemukan pada lokasi Arfai (stasiun 1)

\begin{tabular}{|c|c|c|c|c|c|c|}
\hline No & Division & Class & Order & Family & Genus & Species \\
\hline 1 & Chlorophyta & Chlorophyceae & Bryopsidales & Caulerpaceae & Caulerpa & $\begin{array}{l}\text { Caulerpa racemosa } \\
\text { Var occidentalis } \\
\text { (J.Agardh) } \\
\text { Boergensen, } 1898\end{array}$ \\
\hline 2 & Chlorophyta & Chlorophyceae & Bryopsidales & Halimedaceae & Halimeda & $\begin{array}{l}\text { Halimeda } \\
\text { borneensis } \\
\text { (W.R.Taylor), } 1950\end{array}$ \\
\hline 3 & Chlorophyta & Chlorophyceae & Bryopsidales & Halimedaceae & Halimeda & $\begin{array}{l}\text { Halimeda } \\
\text { cylindraceae } \\
\text { Decaisne, } 1842\end{array}$ \\
\hline 4 & Chlorophyta & Chlorophyceae & Bryopsidales & Halimedaceae & Halimeda & $\begin{array}{l}\text { Halimeda cunneata } \\
\text { Hering, } 1846\end{array}$ \\
\hline 5 & Chlorophyta & Chlorophyceae & Bryopsidales & Halimedaceae & Halimeda & $\begin{array}{l}\text { Halimeda opuntia } \\
\text { (Linnaeus) } \\
\text { Lamouroux, } 1758\end{array}$ \\
\hline 6 & Chlorophyta & Chlorophyceae & Bryopsidales & Halimedaceae & Halimeda & $\begin{array}{l}\text { Halimeda } \\
\text { macroloba } \\
\text { Decaisne, } 1841\end{array}$ \\
\hline 7 & Chlorophyta & Chlorophyceae & Bryopsidales & Halimedaceae & Halimeda & $\begin{array}{l}\text { Halimeda } \\
\text { macrophysa } \\
\text { Askenasy, } 1888\end{array}$ \\
\hline 8 & Chlorophyta & Chlorophyceae & Ulvales & Ulvaceae & Ulva & $\begin{array}{l}\text { Ulva reticulata } \\
\text { Forsskal, } 1775\end{array}$ \\
\hline 9 & Chlorophyta & Chlorophyceae & Cladophorales & Valoniaceae & Valonia & $\begin{array}{l}\text { Valonia ventricosa } \\
\text { J. Agardh } 1823\end{array}$ \\
\hline 10 & Rhodophyta & Rhodophyceae & Bonnemaisonales & Chaetangiaceae & Actinotrichia & $\begin{array}{l}\text { Actinotrichia fragilis } \\
\text { (Forsskal) Boerge- } \\
\text { sen, } 1775\end{array}$ \\
\hline 11 & Rhodophyta & Rhodophyceae & Crytonemiales & Corallinaceae & Amphiroa & $\begin{array}{l}\text { Amphiroa } \\
\text { fragilissima } \\
\text { (Linnaeus) } \\
\text { Lamouroux, } 1877\end{array}$ \\
\hline 12 & Rhodophyta & Rhodophyceae & Crytonemiales & Corallinaceae & Amphiroa & Amphiroa sp, 1786 \\
\hline 13 & Rhodophyta & Rhodophyceae & Ceramiales & Ceramiceae & Acanthophora & $\begin{array}{l}\text { Acanthophora } \\
\text { spicifera (Vahl.) } \\
\text { Boergesen, 1802 }\end{array}$ \\
\hline 14 & Rhodophyta & Rhodophyceae & Bonnemaisonales & Chaetangiaceae & Galaxaura & $\begin{array}{l}\text { Galaxaura } \\
\text { subfruticulosa } \\
\text { Chou, } 1983\end{array}$ \\
\hline 15 & Phaeophyta & Phaeophyceae & Dictyotales & Dictyotaceae & Dictyota & $\begin{array}{l}\text { Dictyota } \\
\text { bartayresiana } \\
\text { Lamouroux, } 1809\end{array}$ \\
\hline 16 & Phaeophyta & Phaeophyceae & Dictyotales & Dictyotaceae & Padina & $\begin{array}{l}\text { Padina minor } \\
\text { Yamada, } 1925\end{array}$ \\
\hline
\end{tabular}

Tabel 3. Klasifikasi makroalga yang ditemukan pada lokasi Rendani (stasiun 2)

\begin{tabular}{ccccccl}
\hline No & Division & Class & Order & Family & Genus & Species \\
\hline 1 & Chlorophyta & Chlorophyceae & Bryopsidales & Udoteaceae & Avrainvilea & $\begin{array}{l}\text { Avrainvilea erecta } \\
\text { (Barkley) A. } \\
\text { Geppy.1842 }\end{array}$ \\
& & & & & Codiaceae \\
2 & $\begin{array}{l}\text { Chlrorophy } \\
\text { ta }\end{array}$ & Chlorophyceae & Bryopsidales & Codium & $\begin{array}{l}\text { Codule P.C. } \\
\text { Silva, 1952 }\end{array}$ \\
3 & Chlorophyta & Chlorophyceae & Bryopsidales & Halimedaceae & Halimeda & $\begin{array}{l}\text { Halimeda } \\
\text { borneensis } \\
\text { (W.R.Taylor), } 1950 \\
\text { Halimeda }\end{array}$ \\
& & & & & & $\begin{array}{l}\text { Hacroloba } \\
\text { Decaisne, } 1841\end{array}$ \\
\hline
\end{tabular}


Lanjutan Tabel 3. Klasifikasi makroalga yang ditemukan pada lokasi Rendani (stasiun 2)

\begin{tabular}{|c|c|c|c|c|c|c|}
\hline No & Division & Class & Order & Family & Genus & Species \\
\hline 6 & Chlorophyta & Chlorophyceae & Bryopsidales & Halimedaceae & Halimeda & $\begin{array}{l}\text { Halimeda opuntia } \\
\text { (Linnaeus) } \\
\text { Lamouroux, } 1758\end{array}$ \\
\hline 7 & Rhodophyta & Rhodophyceae & Ceramiales & Ceramiceae & Acanthophora & $\begin{array}{l}\text { Acanthophora } \\
\text { spicifera (Vahl.) } \\
\text { Boergesen, 1802 }\end{array}$ \\
\hline 8 & Rhodophyta & Rhodophyceae & Bonnemaisonales & Chaetangiaceae & Actinotrichia & $\begin{array}{l}\text { Actinotrichia } \\
\text { fragilis (Forsskal) } \\
\text { Boergesen, } 1775\end{array}$ \\
\hline 9 & Rhodophyta & Rhodophyceae & Crytonemiales & Corallinaceae & Amphiroa & $\begin{array}{l}\text { Amphiroa } \\
\text { fragilissima } \\
\text { (Linnaeus) } \\
\text { Lamouroux, } 1877\end{array}$ \\
\hline 10 & Rhodophyta & Rhodophyceae & Crytonemiales & Corallinaceae & Amphiroa & Amphiroa $s p, 1786$ \\
\hline 11 & Rhodophyta & Rhodophyceae & Bonnemaisonales & Chaetangiaceae & Galaxaura & $\begin{array}{l}\text { Galaxaura } \\
\text { rugosa (Solander) } \\
\text { Lamouroux, } 1816\end{array}$ \\
\hline 12 & Rhodophyta & Rhodophyceae & Bonnemaisonales & Chaetangiaceae & Galaxaura & $\begin{array}{l}\text { Galaxaura } \\
\text { subfruticulosa } \\
\text { Chou, } 1983\end{array}$ \\
\hline 13 & Phaeophyta & Phaeophyceae & Dictyotales & Dictyotaceae & Padina & $\begin{array}{l}\text { Padina minor } \\
\text { Yamada, } 1925\end{array}$ \\
\hline 14 & Phaeophyta & Phaeophyceae & Fucales & Sargassaceae & Sargassum & $\begin{array}{l}\text { Sargassum } \\
\text { polycystum C.A } \\
\text { Agardh, } 1824\end{array}$ \\
\hline
\end{tabular}

Tabel 4. Klasifikasi makroalga yang ditemukan pada lokasi Pasir Putih (stasiun 3)

\begin{tabular}{|c|c|c|c|c|c|c|}
\hline No & Division & Class & Order & Family & Genus & Species \\
\hline 1 & Chlorophyta & Chlorophyceae & Cladophorales & Cladophoraceae & Chaetomorpha & $\begin{array}{l}\text { Chaetomorpha } \\
\text { crassa (Ag.) } \\
\text { Kuetzing, } 1895\end{array}$ \\
\hline 2 & Chlrorophyta & Chlorophyceae & Bryopsidales & Codiaceae & Codium & $\begin{array}{l}\text { Codium edule P.C. } \\
\text { Silva, } 1952\end{array}$ \\
\hline 3 & Chlorophyta & Chlorophyceae & Bryopsidales & Halimedaceae & Halimeda & $\begin{array}{l}\text { Halimeda } \\
\text { borneensis } \\
\text { (W.R.Taylor), } 1950\end{array}$ \\
\hline 4 & Chlorophyta & Chlorophyceae & Bryopsidales & Halimedaceae & Halimeda & $\begin{array}{l}\text { Halimeda } \\
\text { laccunalis Taylor, } \\
1959\end{array}$ \\
\hline 5 & Chlorophyta & Chlorophyceae & Bryopsidales & Halimedaceae & Halimeda & $\begin{array}{l}\text { Halimeda } \\
\text { macrophysa } \\
\text { Askenasy, } 1888\end{array}$ \\
\hline 6 & Chlorophyta & Chlorophyceae & Bryopsidales & Halimedaceae & Halimeda & $\begin{array}{l}\text { Halimeda opuntia } \\
\text { (Linnaeus) } \\
\text { Lamouroux, } 1758\end{array}$ \\
\hline 7 & Chlorophyta & Chlorophyceae & Ulvales & Ulvaceae & Ulva & $\begin{array}{l}\text { Ulva reticulata } \\
\text { Forsskal, } 1775\end{array}$ \\
\hline 8 & Rhodophyta & Rhodophyceae & Bonnemaisonales & Chaetangiaceae & Actinotrichia & $\begin{array}{l}\text { Actinotrichia } \\
\text { fragilis (Forsskal) } \\
\text { Boergesen, } 1775\end{array}$ \\
\hline 9 & Rhodophyta & Rhodophyceae & Crytonemiales & Corallinaceae & Amphiroa & $\begin{array}{l}\text { Amphiroa } \\
\text { fragilissima } \\
\text { (Linnaeus) } \\
\text { Lamouroux, } 1877\end{array}$ \\
\hline 10 & Rhodophyta & Rhodophyceae & Crytonemiales & Corallinaceae & Amphiroa & Amphiroa sp, 1786 \\
\hline 11 & Rhodophyta & Rhodophyceae & Gigartinales & Solieriaceae & Eucheuma & $\begin{array}{l}\text { Eucheuma } \\
\text { denticulatum } \\
\text { (Burman) Collins } \\
\text { dan Harvey, } 1917\end{array}$ \\
\hline
\end{tabular}


Lanjutan Tabel 4. Klasifikasi makroalga yang ditemukan pada lokasi Pasir Putih (stasiun 3)

\begin{tabular}{|c|c|c|c|c|c|c|}
\hline No & Division & Class & Order & Family & Genus & Species \\
\hline 12 & Rhodophyta & Rhodophyceae & Bonnemaisonales & Chaetangiaceae & Galaxaura & $\begin{array}{l}\text { Galaxaura } \\
\text { subfruticulosa } \\
\text { Chou, } 1983\end{array}$ \\
\hline 13 & Rhodophyta & Rhodophyceae & Gigartinales & Gracilariaceae & Gracilaria & $\begin{array}{l}\text { Gracilaria } \\
\text { coronopifolia J. } \\
\text { Agardh, } 1852\end{array}$ \\
\hline 14 & Phaeophyta & Phaeophyceae & Dictyotales & Dictyotaceae & Padina & $\begin{array}{l}\text { Padina minor } \\
\text { Yamada, } 1925\end{array}$ \\
\hline 15 & Phaeophyta & Phaeophyceae & Fucales & Sargassaceae & Sargassum & $\begin{array}{l}\text { Sargassum } \\
\text { polycystum C.A } \\
\text { Agardh, } 1824\end{array}$ \\
\hline
\end{tabular}

Tabel 5. Klasifikasi makroalga yang ditemukan pada lokasi Pulau Mansinam (stasiun 4)

\begin{tabular}{|c|c|c|c|c|c|c|}
\hline No & Division & Class & Order & Family & Genus & Species \\
\hline 1 & Chlorophyta & Chlorophyceae & Bryopsidales & Udoteaceae & Avrainvilea & $\begin{array}{l}\text { Avrainvilea erecta } \\
\text { (Barkley) A. } \\
\text { Geppy.1842 }\end{array}$ \\
\hline 2 & Chlorophyta & Chlorophyceae & Dasycladales & Dasycladaceae & Bornetella & $\begin{array}{l}\text { Bornetella nitida } \\
\text { Munier-Chalmas, } \\
1887\end{array}$ \\
\hline 3 & Chlorophyta & Chlorophyceae & Bryopsidales & Caulerpaceae & Caulerpa & $\begin{array}{l}\text { Caulerpa racemosa } \\
\text { Var occidentalis } \\
\text { (J.Agardh) } \\
\text { Boergensen, } 1898\end{array}$ \\
\hline 4 & Chlorophyta & Chlorophyceae & Bryopsidales & Halimedaceae & Halimeda & $\begin{array}{l}\text { Halimeda } \\
\text { borneensis } \\
\text { (W.R.Taylor), } 1950\end{array}$ \\
\hline 5 & Chlorophyta & Chlorophyceae & Bryopsidales & Halimedaceae & Halimeda & $\begin{array}{l}\text { Halimeda cunneata } \\
\text { Hering, } 1846\end{array}$ \\
\hline 6 & Chlorophyta & Chlorophyceae & Bryopsidales & Halimedaceae & Halimeda & $\begin{array}{l}\text { Halimeda } \\
\text { cylindraceae } \\
\text { Decaisne, } 1842\end{array}$ \\
\hline 7 & Chlorophyta & Chlorophyceae & Bryopsidales & Halimedaceae & Halimeda & $\begin{array}{l}\text { Halimeda } \\
\text { macroloba } \\
\text { Decaisne, } 1841\end{array}$ \\
\hline 8 & Chlorophyta & Chlorophyceae & Bryopsidales & Halimedaceae & Halimeda & $\begin{array}{l}\text { Halimeda } \\
\text { macrophysa } \\
\text { Askenasy, } 1888\end{array}$ \\
\hline 9 & Chlorophyta & Chlorophyceae & Bryopsidales & Halimedaceae & Halimeda & $\begin{array}{l}\text { Halimeda opuntia } \\
\text { (Linnaeus) } \\
\text { Lamouroux, } 1758\end{array}$ \\
\hline 10 & Chlorophyta & Chlorophyceae & Ulvales & Ulvaceae & Ulva & $\begin{array}{l}\text { Ulva reticulata } \\
\text { Forsskal, } 1775\end{array}$ \\
\hline 11 & Chlorophyta & Chlorophyceae & Cladophorales & Valoniaceae & Valonia & $\begin{array}{l}\text { Valonia ventricosa } \\
\text { J. Agardh } 1823\end{array}$ \\
\hline 12 & Rhodophyta & Rhodophyceae & Ceramiales & Ceramiceae & Acanthophora & $\begin{array}{l}\text { Acanthophora } \\
\text { spicifera (Vahl.) } \\
\text { Boergesen, 1802 }\end{array}$ \\
\hline 13 & Rhodophyta & Rhodophyceae & Bonnemaisonales & Chaetangiaceae & Actinotrichia & $\begin{array}{l}\text { Actinotrichia } \\
\text { fragilis (Forsskal) } \\
\text { Boergesen, } 1775\end{array}$ \\
\hline 14 & Rhodophyta & Rhodophyceae & Crytonemiales & Corallinaceae & Amphiroa & $\begin{array}{l}\text { Amphiroa } \\
\text { fragilissima } \\
\text { (Linnaeus) } \\
\text { Lamouroux, } 1877\end{array}$ \\
\hline 15 & Rhodophyta & Rhodophyceae & Bonnemaisonales & Chaetangiaceae & Galaxaura & $\begin{array}{l}\text { Galaxaura } \\
\text { rugosa (Solander) } \\
\text { Lamouroux, } 1816\end{array}$ \\
\hline
\end{tabular}


Lanjutan Tabel 5. Klasifikasi makroalga yang ditemukan pada lokasi Pulau Mansinam (stasiun 4)

\begin{tabular}{|c|c|c|c|c|c|c|}
\hline No & Division & Class & Order & Family & Genus & Species \\
\hline 16 & Rhodophyta & Rhodophyceae & Bonnemaisonales & Chaetangiaceae & Galaxaura & $\begin{array}{l}\text { Galaxaura } \\
\text { subfruticulosa } \\
\text { Chou, } 1983\end{array}$ \\
\hline 17 & Rhodophyta & Rhodophyceae & Gigartinales & Gracilariaceae & Gracilaria & $\begin{array}{l}\text { Gracilaria } \\
\text { coronopifolia J. } \\
\text { Agardh, } 1852\end{array}$ \\
\hline 18 & Phaeophyta & Phaeophyceae & Dictyotales & Dictyotaceae & Dictyota & $\begin{array}{l}\text { Dictyota } \\
\text { bartayresiana } \\
\text { Lamouroux, } 1809\end{array}$ \\
\hline 19 & Phaeophyta & Phaeophyceae & Dictyotales & Dictyotaceae & Hydroclathrus & $\begin{array}{l}\text { Hydroclathrus } \\
\text { clatratus } \\
\text { (C.Agardh) Howe, } \\
1813\end{array}$ \\
\hline 20 & Phaeophyta & Phaeophyceae & Dictyotales & Dictyotaceae & Padina & $\begin{array}{l}\text { Padina australis } \\
\text { Hauck, } 1887\end{array}$ \\
\hline 21 & Phaeophyta & Phaeophyceae & Fucales & Fucaceae & Turbinaria & $\begin{array}{l}\text { Turbinaria ornata } \\
\text { (Turner) J. Agardh, } \\
1848\end{array}$ \\
\hline
\end{tabular}

Tabel 6. Klasifikasi makroalga yang ditemukan pada lokasi Pulau Lemon (stasiun 5)

\begin{tabular}{|c|c|c|c|c|c|c|}
\hline No & Division & Class & Order & Family & Genus & Species \\
\hline 1 & Chlorophyta & Chlorophyceae & Dasycladales & Dasycladaceae & Bornetella & $\begin{array}{l}\text { Bornetella nitida } \\
\text { Munier-Chalmas, } \\
1887\end{array}$ \\
\hline 2 & Chlorophyta & Chlorophyceae & Bryopsidales & Caulerpaceae & Caulerpa & $\begin{array}{l}\text { Caulerpa racemosa } \\
\text { Var occidentalis } \\
\text { (J.Agardh) } \\
\text { Boergensen, } 1898\end{array}$ \\
\hline 3 & Chlrorophyta & Chlorophyceae & Bryopsidales & Codiaceae & Codium & $\begin{array}{l}\text { Codium edule P.C. } \\
\text { Silva, } 1952\end{array}$ \\
\hline 4 & Chlorophyta & Chlorophyceae & Bryopsidales & Halimedaceae & Halimeda & $\begin{array}{l}\text { Halimeda } \\
\text { borneensis } \\
\text { (W.R.Taylor), } 1950\end{array}$ \\
\hline 5 & Chlorophyta & Chlorophyceae & Bryopsidales & Halimedaceae & Halimeda & $\begin{array}{l}\text { Halimeda cunneata } \\
\text { Hering, } 1846\end{array}$ \\
\hline 6 & Chlorophyta & Chlorophyceae & Bryopsidales & Halimedaceae & Halimeda & $\begin{array}{l}\text { Halimeda } \\
\text { cylindraceae } \\
\text { Decaisne, } 1842\end{array}$ \\
\hline 7 & Chlorophyta & Chlorophyceae & Bryopsidales & Halimedaceae & Halimeda & $\begin{array}{l}\text { Halimeda } \\
\text { macroloba } \\
\text { Decaisne, } 1841\end{array}$ \\
\hline 8 & Chlorophyta & Chlorophyceae & Bryopsidales & Halimedaceae & Halimeda & $\begin{array}{l}\text { Halimeda } \\
\text { macrophysa } \\
\text { Askenasy, } 1888\end{array}$ \\
\hline 9 & Chlorophyta & Chlorophyceae & Bryopsidales & Halimedaceae & Halimeda & $\begin{array}{l}\text { Halimeda opuntia } \\
\text { (Linnaeus) } \\
\text { Lamouroux, } 1758\end{array}$ \\
\hline 10 & Chlorophyta & Chlorophyceae & Cladophorales & Valoniaceae & Valonia & $\begin{array}{l}\text { Valonia ventricosa } \\
\text { J. Agardh } 1823\end{array}$ \\
\hline 11 & Chlorophyta & Chlorophyceae & Ulvales & Ulvaceae & Ulva & $\begin{array}{l}\text { Ulva reticulata } \\
\text { Forsskal, } 1775\end{array}$ \\
\hline 12 & Rhodophyta & Rhodophyceae & Ceramiales & Ceramiceae & Acanthophora & $\begin{array}{l}\text { Acanthophora } \\
\text { spicifera (Vahl.) } \\
\text { Boergesen, 1802 }\end{array}$ \\
\hline 13 & Rhodophyta & Rhodophyceae & Bonnemaisonales & Chaetangiaceae & Actinotrichia & $\begin{array}{l}\text { Actinotrichia } \\
\text { fragilis (Forsskal) } \\
\text { Boergesen, } 1775\end{array}$ \\
\hline
\end{tabular}


Lanjutan Tabel 6. Klasifikasi makroalga yang ditemukan pada lokasi Pulau Lemon (stasiun 5)

\begin{tabular}{|c|c|c|c|c|c|c|}
\hline No & Division & Class & Order & Family & Genus & Species \\
\hline 14 & Rhodophyta & Rhodophyceae & Crytonemiales & Corallinaceae & Amphiroa & $\begin{array}{l}\text { Amphiroa } \\
\text { fragilissima } \\
\text { (Linnaeus) } \\
\text { Lamouroux, } 1877\end{array}$ \\
\hline 15 & Rhodophyta & Rhodophyceae & Crytonemiales & Corallinaceae & Amphiroa & Amphiroa sp, 1786 \\
\hline 16 & Rhodophyta & Rhodophyceae & Bonnemaisonales & Chaetangiaceae & Galaxaura & $\begin{array}{l}\text { Galaxaura } \\
\text { rugosa (Solander) } \\
\text { Lamouroux, } 1816\end{array}$ \\
\hline 17 & Rhodophyta & Rhodophyceae & Bonnemaisonales & Chaetangiaceae & Galaxaura & $\begin{array}{l}\text { Galaxaura } \\
\text { subfruticulosa } \\
\text { Chou, } 1983\end{array}$ \\
\hline 18 & Phaeophyta & Phaeophyceae & Dictyotales & Dictyotaceae & Dictyota & $\begin{array}{l}\text { Dictyota } \\
\text { bartayresiana } \\
\text { Lamouroux, } 1809\end{array}$ \\
\hline 19 & Phaeophyta & Phaeophyceae & Dictyotales & Dictyotaceae & Hydroclathrus & $\begin{array}{l}\text { Hydroclathrus } \\
\text { clatratus } \\
\text { (C.Agardh) } \\
\text { Howe, } 1813\end{array}$ \\
\hline 20 & Phaeophyta & Phaeophyceae & Dictyotales & Dictyotaceae & Padina & $\begin{array}{l}\text { Padina australis } \\
\text { Hauck, } 1887\end{array}$ \\
\hline 21 & Phaeophyta & Phaeophyceae & Fucales & Fucaceae & Turbinaria & $\begin{array}{l}\text { Turbinaria ornata } \\
\text { (Turner) J. Agardh, } \\
1848\end{array}$ \\
\hline
\end{tabular}

Secara keseluruhan komunitas makroalga di perairan Manokwari di dominasi oleh alga hijau yang memiliki komposisi spesies dan jumlah spesies yang lebih besar kemudian diikuti oleh alga merah dan alga coklat. Daerah outland Pulau Mansinam (stasiun 4) dan Pulau Lemon (stasiun 5) komposisi dan jumlah spesies lebih tinggi dibandingkan dengan daerah mainland lokasi Arfai (stasiun 1), Rendani (stasiun 2) dan Pasir Putih (stasiun 3) hal ini diduga disebabkan oleh tipe tekstur substrat pada lokasi penelitian di daerah outland tipe substrat cenderung lebih didominasi oleh pasir bercampur hancuran/patahan karang mati kategori pasir (sedimen carbonat) dibandingkan dengan daerah mainland kategori pasir berlempung (sedimen terrigenous berasal dari daratan). Huettel \& Gust (1992) menyatakan distribusi ukuran partikel sedimen sangat mempengaruhi pertukaran air pori bagian holdfast makroalga dengan kolom air di bagian atasnya. Pada distribusi ukuran partikel ke arah debu dan liat (terrigenous) akan menyebabkan pertukaran air pori dengan kolom air menjadi rendah, kondisi sebaliknya akan dialami oleh makroalga jika menempati tipe sedimen pasir kasar, patahan dan pecahan karang (carbonat) dimana pertukaran air pori dengan kolom air sangat tinggi dengan arus yang membawa nutrien (unsur hara) untuk pertumbuhan dan perkembangan makroalga. Pernyataan ini didukung oleh Soegiarto et al. (2011) mengemukakan bahwa alga hidup sebagai fitobentos dengan menancapkan atau melekatkan dirinya pada substrat lumpur, pasir, karang, patahan fragmen karang mati, batu maupun kayu. Perbedaan struktur habitat substrat sangat menentukkan pertumbuhan rumput laut. Tingginya komposisi spesies daerah outland berkaitan dengan kondisi habitat perairan yang bersih, tidak ditemui adanya sedimentasi dan kekeruhan, pergerakan air yang baik, buangan sampah tidak terlihat di bandingkan dengan lokasi mainland.

Parameter fisik arus di lokasi penelitian juga mempengaruhi komposisi dan jumlah spesis yang ditemukan di mana berdasarkan hasil analisis kecepatan arus dengan alat current meter lokasi pulau Mansinam (stasiun 4) dan pulau Lemon (stasiun 5) memiliki kecepatan arus lebih tinggi rata-rata $0.35 \mathrm{~m} / \mathrm{d}$ dibandingkan dengan lokasi Arfai (stasiun 1), Rendani (stasiun 2) dan Pasir Putih (stasiun 3) rata-rata 0.1 $\mathrm{m} / \mathrm{d}$. Semakin kuat arus suatu perairan pertumbuhan rumput laut akan semakin cepat karena difusi nutrien kedalaman sel tanaman rumput laut semakin banyak sehingga metabolisme dan perkembangan sel dipercepat proses pertumbuhannya (Soegiarto et al. 2011). Peran arus adalah menghindari akumulasi silt dan penempelan 
epifit yang melekat pada thallus yang dapat menghalangi pertumbuhan rumput laut.

\section{Kepadatan jenis makroalga}

Berdasarkan hasil perhitungan yang ditunjukkan pada Tabel 7 didapat histogram kepadatan rata-rata makroalga (Ind $/ \mathrm{m}^{2}$ ) di 5 lokasi penelitian. Kepadatan makroalga tertinggi di daerah outland stasiun pulau Mansinam (7.46 \pm 5.44$)$ diikuti oleh stasiun Pulau Lemon (6.41 \pm 5.16$)$ untuk daerah mainland terendah stasiun Rendani $(3.50 \% \pm 2.21)$, stasiun Arfai (4.25 \pm 3.09$)$ dan stasiun Pasir Putih (4.97 \pm 3.26$)$ seperti ditunjukkan pada Gambar 3.

Secara keseluruhan hasil analisis terhadap kepadatan jenis makroalga yang ditemukan pada lima lokasi penelitian menunjukkan bahwa daerah outland lokasi Pulau Mansinam (stasiun 4) dan lokasi Pulau Lemon (stasiun 5) memiliki kepadatan spesies dalam hal ini jumlah individu $/ \mathrm{m}^{2}$ lebih tinggi di bandingkan dengan daerah mainland lokasi Rendani (stasiun 2), lokasi Arfai (stasiun 1) dan lokasi Pasir Putih (stasiun 3). Kepadatan tertinggi di daerah outland diduga berkaitan dengan kondisi habitat yang masih baik, perairan jernih tidak keruh dan tidak ditemukan adanya sedimentasi dibandingkan dengan daerah mainland dengan topografi pantai landai, dangkal dan keruh yang diduga banyak menerima masukkan bahan tersuspensi yang berasal dari sedimentasi daratan (partikel organik lumpur) dan limbah antropogenik sehingga tidak baik untuk pertumbuhan makroalga (Soegiarto et al. 2011). Hasil penelitian menunjukkan masing-masing lokasi memiliki kepadatan spesies yang berbeda. Hal ini diduga berkaitan dengan kondisi fisik abiotiknya seperti tipe substrat, kecerahan, sirkulasi kecepatan arus dikaitkan dengan nutrien, adaptasi makroalga dengan lingkungan itu sendiri dan buangan limbah antropogenik di daerah penelitian. Pernyataan ini di dukung oleh Sjöö (2010) mengemukakan bahwa faktor lingkungan fisik-kimia sangat berpengaruh terhadap pertumbuhan dan perkembangan makroalga.

Penelitian menunjukkan bahwa sebaran kepadatan makroalga berhubungan dengan tipe habitat dan dominasi jenis makroalga. Nilai Kepadatan makroalga di lokasi penelitian dapat dilihat pada Tabel 7 . Makroalga jenis Padina australis di Lemon memiliki kepadatan tertinggi 20.30 Ind $/ \mathrm{m}^{2}$, Mansinam 19.60 Ind $/ \mathrm{m}^{2}$ daerah outland dimana makroalga ini memiliki holdfast berbentuk cakram yang mampu mengkait substrat keras, fragmen patahan karang dengan arus yang deras berombak tipe sedimen carbonat dengan perairan yang jernih sangat disukai oleh jenis makroalga ini dan beberapa makroalga lain seperti Halimeda opuntia, Halimeda macrophysa, Halimeda cylindraceae, dan Hydroclathrus clatratus sedangkan untuk daerah mainland beberapajenis makroalga seperti Actinotrichia fragilis, Amphiroa fragilissima, Avrainvilea erecta, Amphiroa sp menyukai substrat pasir berlumpur halus dengan akar holdfast berupa kumpulan akar serabut menancap, menempel atau mengikat partikel-partikel pasir dengan tipe substrat pasir berlumpur sedimen terrigenous berasal dari daratan.

Kondisi pola sebaran makroalga dengan tipe habitat berupa partikel-partikel pasir, lumpur halus, patahan frakmen pecahan karang, pasir kasar, rataan karang dan batu karang atau struktur tipe substrat sangat menentukkan variasi jenis makroalga yang tumbuh di lokasi penelitian (Kadi 2014). Nilai kepadatan makroalga di lokasi penelitian dapat di lihat pada Tabel 7 .

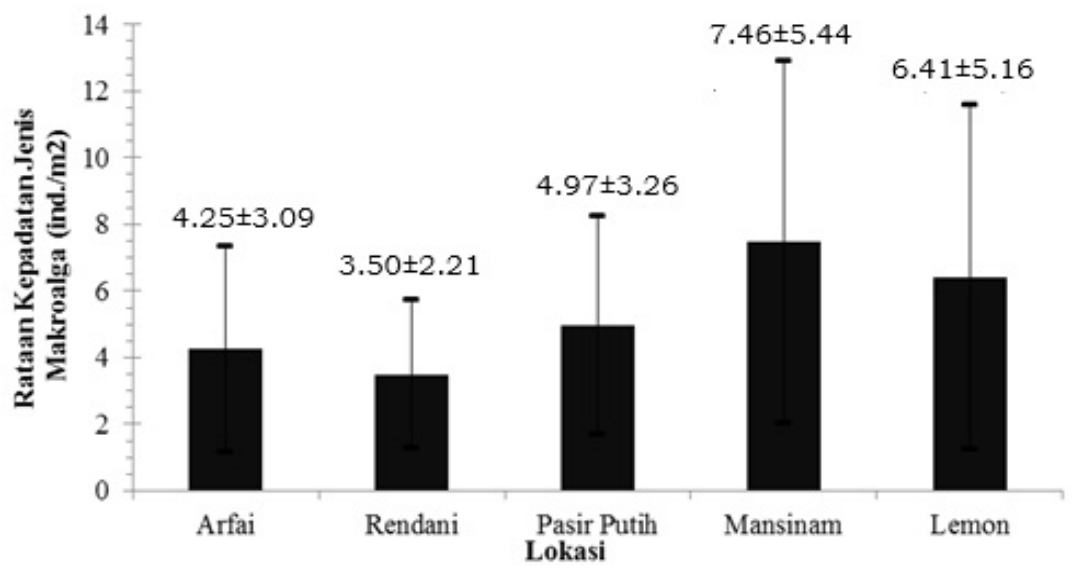

Gambar 3. Histogram kepadatan rata-rata makroalga $\left(\mathrm{Ind} / \mathrm{m}^{2}\right)$ di lokasi penelitian 
Tabel 7. Kepadatan jenis makroalga $\left(\mathrm{Ind} / \mathrm{m}^{2}\right)$ di 5 lokasi penelitian

\begin{tabular}{|c|c|c|c|c|c|}
\hline \multirow[b]{2}{*}{ Spesies Makroalga } & \multicolumn{5}{|c|}{ Lokasi } \\
\hline & $\begin{array}{c}\text { Arfai } \\
\text { Di }\left(\text { Ind } / \mathrm{m}^{2}\right)\end{array}$ & $\begin{array}{c}\text { Rendani } \\
\left.\text { Di (Ind } / \mathbf{m}^{2}\right)\end{array}$ & $\begin{array}{l}\text { Pasir Putih } \\
\left.\text { Di (Ind } / \mathrm{m}^{2}\right)\end{array}$ & $\begin{array}{c}\text { Mansinam } \\
\left.\text { Di (Ind } / \mathbf{m}^{2}\right)\end{array}$ & $\begin{array}{c}\text { Lemon } \\
\text { Di (Ind/ } \\
\text { m }^{2} \text { ) }\end{array}$ \\
\hline Acanthophora spicifera & 3.20 & 6.00 & - & 2.07 & 2.00 \\
\hline Actinotrichia fragilis & 4.87 & 6.67 & 1.47 & 1.67 & 2.90 \\
\hline Amphiroa fragilissima & 7.73 & 1.87 & 3.60 & 8.73 & 7.00 \\
\hline Amphiroa $s p$ & 3.73 & 3.13 & 4.27 & - & 3.90 \\
\hline Avrainvilea erecta & - & 1.60 & - & 2.07 & - \\
\hline Bornetella nitida & - & - & - & 0.80 & 1.90 \\
\hline Caulerpa racemosa & 1.80 & - & - & 7.07 & 2.90 \\
\hline Chaetomorpha crassa & - & - & 5.00 & - & - \\
\hline Codium edule & - & 2.40 & 5.40 & - & 3.40 \\
\hline Dictyota bartayresiana & 1.33 & - & - & 4.67 & 6.10 \\
\hline $\begin{array}{l}\text { Eucheuma } \\
\text { denticulatum }\end{array}$ & - & - & 0.47 & - & - \\
\hline Galaxaura rugosa & - & 0.73 & - & 8.67 & 4.90 \\
\hline $\begin{array}{l}\text { Galaxaura } \\
\text { subfruticulosa }\end{array}$ & 2.47 & 2.27 & 4.53 & 5.00 & 4.30 \\
\hline Gracilaria coronopifolia & - & - & 2.07 & 6.20 & - \\
\hline Halimeda borneensis & 9.47 & 4.87 & 8.53 & 9.07 & 6.00 \\
\hline Halimeda cunneata & 2.27 & - & - & 9.67 & 3.80 \\
\hline Halimeda cylindraceae & 1.60 & - & - & 10.20 & 17.50 \\
\hline Halimeda laccunalis & - & - & 3.53 & - & - \\
\hline Halimeda macroloba & 8.93 & 2.07 & - & 6.33 & 2.90 \\
\hline Halimeda macrophysa & 1.67 & 4.60 & 8.60 & 15.07 & 12.30 \\
\hline Halimeda opuntia & 9.80 & 3.73 & 7.93 & 17.27 & 9.10 \\
\hline $\begin{array}{l}\text { Hydroclathrus } \\
\text { clatratus }\end{array}$ & - & - & - & 7.20 & 10.00 \\
\hline Padina australis & - & - & - & 19.60 & 20.30 \\
\hline Padina minor & 3.27 & 6.33 & 10.13 & - & - \\
\hline Sargassum polycystum & - & 2.80 & 2.53 & - & - \\
\hline Turbinaria ornata & - & - & - & 5.00 & 7.80 \\
\hline Ulva reticulata & 3.67 & - & 6.53 & 8.27 & 3.50 \\
\hline Valonia ventricosa & 2.27 & - & - & 2.07 & 2.10 \\
\hline Jumlah Total & 68.07 & 49.07 & 74.59 & 156.67 & 134.60 \\
\hline Rataan \pm STD & $4.25 \pm 3.09$ & $3.50 \pm 2.21$ & $4.97 \pm 3.26$ & $7.46 \pm 5.44$ & $6.41 \pm 5.16$ \\
\hline
\end{tabular}




\section{Parameter fisika - kimia perairan}

Pertumbuhan makroalga di pengaruh oleh faktor lingkungan baik fisik maupun kimia. Hasil pengukuran parameter tersebut seperti di tunjukkan pada (Tabel 8).

Suhu

Suhu merupakan salah satu faktor yang sangat penting dalam mengatur proses metabolisme dan penyebaran organisme. Kebanyakan organisme laut seperti makroalga mengalami adaptasi untuk hidup dan berkembang biak dalam kisaran suhu yang sempit dari kisaran total antara $0-40{ }^{\circ} \mathrm{C}$ (Nybakken 1992).

Hasil pengukuran suhu perairan di 5 lokasi penelitian memiliki kisaran yang sempit dan berfluktuasi tidak terlalu besar yakni dari $29.9{ }^{\circ} \mathrm{C}$ sampai $31.73{ }^{\circ} \mathrm{C}$ (Tabel
8), dengan suhu terendah di lokasi Rendani (stasiun 2) rata- rata $29.9{ }^{\circ} \mathrm{C} \pm 0.79$, lokasi Pasir Putih (stasiun 3) rata - rata 29.93 ${ }^{\circ} \mathrm{C} \pm 0.11$. Nilai kisaran suhu tertinggi terdapat pada lokasi pulau Mansinam (stasiun 4) rata-rata $31.73{ }^{\circ} \mathrm{C} \pm 0.64$, lokasi pulau Lemon (stasiun 5) rata-rata 31.5 ${ }^{\circ} \mathrm{C} \pm 0.60$ dan Arfai (stasiun 1) rata-rata $31.33{ }^{\circ} \mathrm{C} \pm 0.57$ dibandingkan dengan nilai baku mutu maka nilai suhu tertinggi telah melebihi baku mutu $\left(>30^{\circ} \mathrm{C}\right)$, namun nilai yang didapat dari hasil penelitian tersebut merupakan kisaran yang normal bagi pertumbuhan makroalga sebagaimana dikemukakan Dawes (1981) bahwa kisaran suhu yang baik bagi pertumbuhan makroalga berkisar $21^{\circ} \mathrm{C}-32.4^{\circ} \mathrm{C}$. Hutagalung (1988) menyatakan batas ambang suhu untuk pertumbuhan alga hijau, alga coklat dan alga merah adalah $34.5^{\circ} \mathrm{C}$ sedangkan untuk alga hijau biru $85^{\circ} \mathrm{C}$.

Tabel 8. Hasil pengukuran parameter fisika-kimia di lokasi penelitian

\begin{tabular}{|c|c|c|c|c|c|c|}
\hline \multirow{3}{*}{$\begin{array}{c}\text { Parameter } \\
\text { Lingkungan }\end{array}$} & \multicolumn{5}{|c|}{ Lokasi } & \multirow{3}{*}{$\begin{array}{c}\text { Standar } \\
\text { Baku } \\
\text { Mutu }\end{array}$} \\
\hline & Arfai & Rendani & Pasir Putih & Mansinam & Lemon & \\
\hline & $\begin{array}{c}\text { Min-Max } \\
\text { (Rata } \pm \text { STD) }\end{array}$ & $\begin{array}{c}\text { Min-Max } \\
\text { (Rata } \pm \text { STD) }\end{array}$ & $\begin{array}{c}\text { Min-Max } \\
\text { (Rata } \pm \text { STD) }\end{array}$ & $\begin{array}{c}\text { Min-Max } \\
\text { (Rata } \pm \text { STD) }\end{array}$ & $\begin{array}{c}\text { Min-Max } \\
\text { (Rata } \pm \text { STD) }\end{array}$ & \\
\hline \multicolumn{7}{|l|}{ Fisika Air } \\
\hline Suhu $\left({ }^{\circ} \mathrm{C}\right)$ & $\begin{array}{c}31.0-32.0 \\
(31.33 \pm 0.57)\end{array}$ & $\begin{array}{c}29.0-30.5 \\
(29.90 \pm 0.79)\end{array}$ & $\begin{array}{c}29.8-30.0 \\
(29.93 \pm 0.11)\end{array}$ & $\begin{array}{c}31.0-32.2 \\
(31.73 \pm 0.64)\end{array}$ & $\begin{array}{c}31.1-32.2 \\
(31.50 \pm 0.60)\end{array}$ & 28-30a \\
\hline $\begin{array}{l}\text { Kedalaman } \\
(\mathrm{m})\end{array}$ & $\begin{array}{c}1.0-1.5 \\
(1.33 \pm 0.28)\end{array}$ & $\begin{array}{c}1.5-1.75 \\
(1.58 \pm 0.14)\end{array}$ & $\begin{array}{c}1.5-2.0 \\
(1.66 \pm 0.28)\end{array}$ & $\begin{array}{c}1.5-2.0 \\
(1.66 \pm 0.28)\end{array}$ & $\begin{array}{c}1.5-2.0 \\
(1.66 \pm 0.28)\end{array}$ & \\
\hline $\begin{array}{l}\text { Kecerahan } \\
(\mathrm{m})\end{array}$ & $\begin{array}{c}3.0-5.0 \\
(4.33 \pm 1.15)\end{array}$ & $\begin{array}{c}3.0-4.0 \\
(3.33 \pm 0.57)\end{array}$ & $\begin{array}{c}4.5-5.0 \\
(4.83 \pm 0.28)\end{array}$ & $\begin{array}{c}8.5-10.0 \\
(9.16 \pm 0.76)\end{array}$ & $\begin{array}{c}9,0-10,0 \\
(9,33 \pm 0,57)\end{array}$ & \\
\hline $\begin{array}{l}\text { Kecepatan } \\
\text { arus }(\mathrm{m} / \mathrm{d})\end{array}$ & $\begin{array}{c}0.1-0.2 \\
(0.13 \pm 0.05)\end{array}$ & $\begin{array}{c}0.1-0.25 \\
(0.15 \pm 0.08)\end{array}$ & $\begin{array}{c}0.1-0.25 \\
(0.18 \pm 0.07)\end{array}$ & $\begin{array}{c}0.25-0.35 \\
(0.30 \pm 0.05)\end{array}$ & $\begin{array}{c}0.3-0.35 \\
(0.31 \pm 0.02)\end{array}$ & \\
\hline $\begin{array}{l}\text { Kekeruhan } \\
\text { (NTU) }\end{array}$ & $\begin{array}{c}3.1-5.13 \\
(3.84 \pm 1.11)\end{array}$ & $\begin{array}{l}9.25-10.30 \\
(9.61 \pm 0.59)\end{array}$ & $\begin{array}{c}3.20-4.10 \\
(3.50 \pm 0.51)\end{array}$ & $\begin{array}{c}0.10-0.19 \\
(0.14 \pm 0.04)\end{array}$ & $\begin{array}{c}0.10-0.22 \\
(0.14 \pm 0.06)\end{array}$ & \\
\hline \multicolumn{7}{|l|}{ Kimia Air } \\
\hline Salinitas (\%о) & $\begin{array}{c}31.0-32.0 \\
(31.66 \pm 0.57)\end{array}$ & $\begin{array}{c}30.0-31.2 \\
(30.80 \pm 0.52)\end{array}$ & $\begin{array}{c}31.0-32.0 \\
(31.66 \pm 0.57)\end{array}$ & $\begin{array}{c}32.5-33.0 \\
(32.83 \pm 0.28)\end{array}$ & $\begin{array}{c}32.0-32.5 \\
(32.16 \pm 0.28)\end{array}$ & $33-34 a$ \\
\hline $\mathrm{pH}$ & $\begin{array}{c}7.58-7.62 \\
(7.59 \pm 0.02)\end{array}$ & $\begin{array}{c}6.0-6.56 \\
(6.25 \pm 0.28)\end{array}$ & $\begin{array}{c}6.50-6.56 \\
(6.53 \pm 0.03)\end{array}$ & $\begin{array}{c}7.73-7.75 \\
(7.74 \pm 0.01)\end{array}$ & $\begin{array}{c}7.73-7.78 \\
(7.76 \pm 0.02)\end{array}$ & $7-8,5 a$ \\
\hline $\mathrm{DO}(\mathrm{mg} / \mathrm{L})$ & $\begin{array}{c}6.64-7.12 \\
(6.84 \pm 0.24)\end{array}$ & $\begin{array}{c}6.98-7.38 \\
(7.13 \pm 0.21)\end{array}$ & $\begin{array}{c}6.45-7.41 \\
(6.88 \pm 0.48)\end{array}$ & $\begin{array}{c}6.87-8.49 \\
(7.69 \pm 0.81)\end{array}$ & $\begin{array}{c}6.02-8.17 \\
(6.88 \pm 1.13)\end{array}$ & $>5 a$ \\
\hline Nitrat (mg/L) & 0.059 & 0.056 & 0.029 & 0.003 & 0.024 & $0.008 a$ \\
\hline $\begin{array}{l}\text { Orthofosfat } \\
\text { (mg/L) }\end{array}$ & 0.008 & 0.019 & 0.010 & 0.006 & 0.010 & $0.015 a$ \\
\hline
\end{tabular}

Keterangan : Angka dalam kurung adalah rata-rata dari tiga kali ulangan \pm standar deviasi a=Kepmen NLH No.51 Tahun 2000 
Kecepatan arus

Arus dan gelombang merupakan faktor pendukung pertumbuhan makroalga, karena gelombang memiliki pengaruh yang besar terhadap aerasi, transport nutrien dan pengadukan air. Hasil penelitian menunjukkan kecepatan arus berkisar antara $0.13 \mathrm{~m} / \mathrm{d}$ sampai $0.31 \mathrm{~m} / \mathrm{d}$ (Tabel 8). Kecepatan arus terendah di lokasi Arfai (stasiun 1) rata - rata $0.13 \mathrm{~m} / \mathrm{d} \pm 0.05$, lokasi Rendani (stasiun 2) rata-rata $0.15 \mathrm{~m} / \mathrm{d} \pm 0.08$, lokasi P.Putih (stasiun 3) rata-rata $0.18 \mathrm{~m} /$ $\mathrm{d} \pm 0.07$. Kecepatan arus tertinggi dari hasil penelitian didapat lokasi pulau Mansinam (stasiun 4) rata-rata $0.30 \mathrm{~m} / \mathrm{d} \pm 0.05$ dan pulau Lemon (stasiun 5) rata-rata $0.31 \mathrm{~m} /$ $\mathrm{d} \pm 0.02$. Kecepatan arus yanglebih besar pada lokasi outland pulau Mansinam dan pulau Lemon diduga kedua perairan ini terletak di daerah luar teluk doreri arus yang kuat dengan kondisi struktur perairannya curam (tubir) dan dipengaruhi oleh jalur tempat masuk keluarnya air pada saat pasang surut di daerah teluk, dibandingkan dengan ketiga lokasi yang lain yang agak terlindung dengan profil pantai landai dekat dengan daratan besar Manokwari (mainland).

Perairan yang agak tenang justru tidak baik bagi habitat makroalga, karena akan menyebabkan terjadinya akumulasi silt (endapan lumpur) dan epifit yang melekat sehingga menghambat pertumbuhan makroalga. Soegiarto et al. (2011) mengatakan semakin kuatnya arus maka pertumbuhan makroalga akan semakin cepat karena difusi nutrien kedalam sel tanaman makroalga semakin banyak sehingga metabolisme dipercepat, kisaran kecepatan arus yang baik dalam daerah areal budidaya rumput laut untuk pertumbuhan berkisar antara $0.2 \mathrm{~m} / \mathrm{d}-0.35$ m/d (Atmadja et al. 1996).

\section{Kekeruhan}

Kekeruhan merupakan fakor pembatas bagi proses fotosintesis dan produksi primer karena mempengaruhi penetrasi cahaya dimana kekeruhan perairan merupakan gambaran sifat optik dari suatu media air yang ditentukkan berdasarkan banyaknya sinar cahaya yang dipancarkan dan diserap oleh partikel-partikel yang ada dalam kolom perairan (Boyd 1988).

Nilai kekeruhan di lokasi penelitian berkisar antara 0.14 NTU sampai 9.61 NTU (Tabel 8). Nilai kekeruhan tinggi daerah mainland pada 3 lokasi yaitu: lokasi Rendani (stasiun 2) rata -rata 9.61 NTU \pm 0.59 , lokasi Arfai (stasiun 1) rata-rata 3.84 NTU \pm 1.11 , lokasi Pasir Putih (stasiun 3) rata-rata 3.50 NTU \pm 0.51 sedangkan outland relatif lebih jernih dengan tingkat kecerahan yang tinggi di mana perairannya agak bersih pada lokasi pulau Mansinam (stasiun 4) rata-rata 0.14 NTU \pm 0.04 dan pulau Lemon (stasiun 5) ratarata 0.14 NTU \pm 0.06 . Tinggi nilai kekeruhan di mainland diduga perairan tersebut banyak menerima masukan bahan tersuspensi yang berasal dari sedimentasi daratan (partikel organik lumpur) dan limbah antropogenik.

\section{Kecerahan}

Kecerahan perairan menentukan jumlah intensitas sinar matahari yang masuk ke suatu perairan. Kemampuan daya tembus sinar matahari ke perairan sangat di tentukkan oleh warna perairan, kandungan bahan-bahan organik maupun anorganik yang tersuspensi di perairan, kepadatan plankton, jasad renik dan detritus (Wardoyo 1981).

Nilai kecerahan di lokasi penelitian berkisar antara $3.33 \mathrm{~m}-9.33 \mathrm{~m}$ (Tabel 8). Nilai kecerahan yang tinggi dengan perairan yang jernih di temukan pada daerah outland 2 lokasi penelitian yaitu lokasi pulau Mansinam (stasiun 4) rata-rata $9.16 \mathrm{~m} \pm 0.76$ dan pulau Lemon (stasiun 5) rata-rata 9.33 $\mathrm{m} \pm 0.57$ sedangkan untuk daerah mainland 3 lokasi lainnya rendah lokasi Rendani (stasiun 2) rata-rata $3.33 \mathrm{~m} \pm 0.57$, lokasi Arfai (stasiun 1) rata-rata $4.33 \mathrm{~m} \pm 1.15$ dan lokasi Pasir Putih (stasiun 3) rata-rata 4.83 $\mathrm{m} \pm 0.28$.

\section{Salinitas}

Distribusi salinitas di perairan dipengaruhi oleh banyak faktor antara lain penguapan, curah hujan, pola sirkulasi air, dan kandungan air tawar yang masuk ke perairan laut. Air tawar yang masuk ke perairan laut dapat berasal dari curah hujan atau aliran permukaan dan aliran sungai (Erina 2006). Penelitian ini nilai salinitas di semua lokasi penelitian memiliki perbedaan nilai yang tidak begitu besar di mana besarnya nilai salinitas yang terukur berkisar antara 30.80\% sampai 32.83\%o (Tabel 8) dengan salinitas tertinggi terdapat pada daerah outland lokasi pulau Mansinam (stasiun 4) rata-rata $32.83 \% \pm 0.28$ sedangkan terendah terdapat pada mainland lokasi Rendani (stasiun 2) rata-rata $30.80 \%$ o.52.

Tingginya nilai salinitas di pulau 
Mansinam (stasiun 4) diduga perairan tersebut terletak jauh dari daratan besar perairan Manokwari (mainland) dengan intrusi kandungan air tawar yang masuk sangat kecil disamping itu proses pengambilan sampel pada siang hari dengan cuaca cerah dengan proses penguapan air laut tinggi. Melihat hasil penelitian yang didapat kisaran salinitas masih dalam kisaran yang baik dalam pertumbuhan makroalga. Lunning (1990) menyatakan bahwa kisaran salinitas yang baik untuk pertumbuhan dan perkembangan makroalga adalah $15 \%$ - 38\%o.

\section{Nilai $p H$}

Nilai $\mathrm{pH}$ sangat penting sebagai parameter kualitas air karena akan mengontrol tipe dan laju kecepatan reaksi beberapa bahan dalam air. Nilai $\mathrm{pH}$ merupakan suatu ekspresi dari konsentrasi ion hydrogen $(\mathrm{H}+)$ di dalam kolom air. Variasi pH umumnya bisa disebabkan oleh proses-proses kimia dan biologis yang dapat menghasilkan senyawa-senyawa yang bersifat asam maupun alkalis. Variasi $\mathrm{pH}$ juga bisa disebabkan masukkan limbah yang bersifat asam atau alkalis dari daratan (Sanusi 2009).

Nilai pH yang diperoleh di 5 lokasi penelitian berkisar 6.25-7.76 (Tabel 8). Konsentrasi nilai $\mathrm{pH}$ terendah terdapat pada daerah mainland lokasi Rendani (stasiun 2) dengan nilai rata - rata $6.25 \pm 0.28$ dan lokasi Pasir Putih (stasiun 3) dengan nilai rata-rata $6.53 \pm 0.03$ kondisi ini diduga sangat terkait dengan masukan bahan organik maupun anorganik dari luar dimana pada perairan Rendani adanya aktivitas pembongkaran dan pelebaran bandara udara rendani yang mengakibatkan bongkahan materialmaterial dan limbah antropogenik disamping itu keberadaan bahan organik yang tinggi akan meningkatkan aktivitas mikrobiologi dalam penguraiannya, sehingga menyebabkan kondisi kolom air yang anoksik. Daerah outland lokasi pulau Lemon (stasiun 5) rata -rata nilai $\mathrm{pH} 7.76 \pm 0.02$ dan lokasi Pulau Mansinam (stasiun 4) rata-rata nilai $\mathrm{pH} 7.74 \pm 0.01$ menunjukkan nilai $\mathrm{pH}$ yang normal dengan kondisi perairan yang jernih. Berdasarkan hasil penelitian pada semua lokasi kisaran nilai $\mathrm{pH}$ masih dalam kategori baik untuk pertumbuhan dan perkembangan makroalga. Lunning (1990) menyatakan pertumbuhan makroalga yang baik tumbuh pada kisaran $\mathrm{pH}$ 6.8-9.6. Aslan (1998) mengemukakan nilai optimal untuk persyaratan lokasi budidaya rumput laut kisaran $\mathrm{pH}$ 7.5-8.0. Perubahan nilai $\mathrm{pH}$ akan mempengaruhi keseimbangan kandungan karbon dioksida $\left(\mathrm{CO}_{2}\right)$ yang secara umum dapat membahayakan kehidupan biota air laut dari tingkat produktivitas primer perairan.

\section{DO (Oksigen terlarut)}

Gas oksigen terlarut dalam air laut dapat berasal dari hasil difusi dari udara (proses aerasi) dan hasil proses fotosintesis di siang hari (Hutagalung \& Rozak 1997). Hasil pengukuran nilai kandungan oksigen terlarut dari 5 lokasi penelitian berkisar antara $6.84 \mathrm{mg} / \mathrm{L}$ sampai $7.69 \mathrm{mg} / \mathrm{L}$ (Tabel 8) dengan DO terendah pada lokasi Arfai (stasiun 1) rata-rata $6.84 \mathrm{mg} / \mathrm{L} \pm 0.24$ diikuti dengan lokasi Pasir Putih (stasiun 3) rata-rata $6.88 \mathrm{mg} / \mathrm{L} \pm 0.48$ dan lokasi Lemon (stasiun 5) rata-rata $6.88 \mathrm{mg} / \mathrm{L} \pm 1.13$ sedangkan nilai DO tertinggi pada lokasi pulau Mansinam (stasiun 4) rata-rata 7.69 $\mathrm{mg} / \mathrm{L} \pm 0.81$ dan lokasi Rendani (stasiun 2) rata-rata $7.13 \mathrm{mg} / \mathrm{L} \pm 0.21$.

Berdasarkan hasil penelitian kisaran nilai DO yang didapat dalam kategori normal dan baik untuk pertumbuhan makroalga sebagaimana yang dikatakan Atmadja, 1996 bahwa kisaran DO yang baik untuk pertumbuhan dan perkembangan makroalga $>6 \mathrm{mg} / \mathrm{L}$. Kadar pengukuran oksigen terlarut dipengaruhi oleh beberapa faktor seperti suhu, salinitas, respirasi dan fotosintesis (Boyd 1988).

\section{Nitrat (NO-3-N)}

Nitrat (NO3-N) adalah bentuk utama unsur nitrogen di perairan alami dan merupakan nutrien utama bagi pertumbuhan dan perkembangan makroalga. Senyawa nitrat dihasilkan dari proses oksidasi sempurna senyawa nitrogen di perairan laut (Sanusi 2009).

Nilai konsentrasi nitrat pada 5 lokasi penelitian berkisar antara $0.003 \mathrm{mg} / \mathrm{L}$ $0.059 \mathrm{mg} / \mathrm{L}$. (Tabel 8), dengan konsentrasi tertinggi terdapat di daerah mainland lokasi Arfai (stasiun 1) nilainya $0.059 \mathrm{mg} / \mathrm{L}$, lokasi Rendani (stasiun 2) nilai $0.056 \mathrm{mg} / \mathrm{L}$ dan diikuti lokasi Pasir Putih nilai konsetrasinya $0.029 \mathrm{mg} / \mathrm{L}$. Tingginya konsentrasi nitrat di 3 lokasi tersebut diduga merupakan hasil degradasi bahan organik dan dekomposisi senyawa-senyawa organik, karena banyak mendapat pengaruh buangan antropogenik dari daratan melalui aliran sungai (fluvial 
transport) yang masuk ke perairan laut (Sanusi 2009). Lokasi pulau Lemon (stasiun 5) nilai konsentrasi nitrat $0.024 \mathrm{mg} / \mathrm{L}$ dan terendah lokasi pulau Mansinam (stasiun 4) nilai konsentrasi $0.003 \mathrm{mg} / \mathrm{L}$. Rendahnya konsentrasi nitrat untuk lokasi pulau Mansinam dan pulau Lemon terkait keberadaan lokasi jauh dari pengaruh aktivitas daratan berupa buangan limbah organic. Berdasarkan hasil penelitian kisaran nilai untuk konsentrasi nitrat masih kategori normal yang baik untuk pertumbuhan makroalga.

\section{Orthofosfat (HPO4-P)}

Perairan laut fosfor tidak ditemukan dalam bentuk bebas melainkan dalam bentuk senyawa anorganik yang terlarut (orthofosfat dan polifosfat) dan senyawa organik berupa partikulat (Sanusi 2009). Orthofosfat merupakan nutrien yang sangat penting untuk pertumbuhan makroalga. Hasil penelitian menunjukkan kisaran nilai konsentrasi orthofosfat di 5 lokasi penelitian berkisar antara $0.006 \mathrm{mg} / \mathrm{L}-0.019 \mathrm{mg} / \mathrm{L}$ (Tabel 8).

Berdasarkan analisis laboratorium konsentrasi nilai orthofosfat tertinggi di lokasi Rendani (stasiun 2) nilai $0.019 \mathrm{mg} / \mathrm{L}$, kemudian diikuti oleh lokasi Pasir Putih (stasiun 3) dan lokasi pulau Lemon (stasiun 5) nilai konsentrasinya $0.010 \mathrm{mg} / \mathrm{L}$. Lokasi Arfai (stasiun 1) nilai konsentrasinya 0.008 $\mathrm{mg} / \mathrm{L}$ dan terendah lokasi pulau Mansinam (stasiun 4) nilai konsentrasinya 0.006 mg/L. Tingginya konsentrasi orthofosfat di lokasi Rendani (stasiun 2) diduga pada saat pengambilan sampel air di lokasi ini adanya kegiatan aktifitas pelebaran bandara udara dengan adanya bongkahan-bongkahan material batuan yang masuk ke perairan pesisir lokasi Rendani sedangkan untuk lokasi pulau Mansinam (stasiun 4) lokasi jauh dari aktivitas daratan. Berdasarkan hasil yang di dapat kisaran nilai orthofosfat dalam penelitian ini masih dalam kategori normal dan baik untuk pertumbuhan dan perkembangan makroalga.

\section{Tekstur Subsrat}

Berdasarkan hasil analisis tekstur substrat terhadap ukuran partikel sedimen pada 5 lokasi penelitian ditemukan persentase dan berat ukuran partikel seperti diperlihatkan pada (Tabel 9).

Tabel 9. Tipe substrat pada 5 lokasi penelitian

\begin{tabular}{|c|c|c|c|c|c|}
\hline \multirow{2}{*}{ Lokasi } & \multicolumn{4}{|c|}{ Berat (gram) dan Persentase (\%) } & \multirow{2}{*}{$\begin{array}{c}\text { Tipe Tekstur/ } \\
\text { Kategori }\end{array}$} \\
\hline & Pasira & Debua & Liata & Kerikil $^{a}$ & \\
\hline Arfai & $\begin{array}{l}67.14 \pm 7.82 \\
84.68 \% \pm 1.50\end{array}$ & $\begin{array}{l}1.03 \pm 1.06 \\
2.23 \% \pm 1.81\end{array}$ & $\begin{array}{l}11.05 \pm 0.43 \\
14.08 \% \pm 2.05\end{array}$ & $24.10 \pm 4.87$ & $\begin{array}{l}\text { Pasir } \\
\text { Berlempung/ } \\
\text { Sedimen } \\
\text { Terrigenous }\end{array}$ \\
\hline Rendani & $\begin{array}{l}73.26 \pm 14.92 \\
96.85 \% \pm 1.19\end{array}$ & $\begin{array}{l}2.27 \pm 0.49 \\
3.14 \% \pm 1.15\end{array}$ & $\begin{array}{l}0 \pm 0 \\
0 \% \pm 0\end{array}$ & $24.46 \pm 14.62$ & $\begin{array}{l}\text { Pasir } \\
\text { Berlempung/ } \\
\text { Sedimen } \\
\text { Terrigenous }\end{array}$ \\
\hline Pasir Putih & $\begin{array}{l}70.53 \pm 13.40 \\
97.24 \% \pm 0.30\end{array}$ & $\begin{array}{l}2.01 \pm 0.52 \\
2.75 \% \pm 0.29\end{array}$ & $\begin{array}{l}0.003 \pm 0.005 \\
0.006 \% \pm 002\end{array}$ & $27.33 \pm 13.86$ & $\begin{array}{l}\text { Pasir } \\
\text { Berlempung/ } \\
\text { Sedimen } \\
\text { Terrigenous }\end{array}$ \\
\hline $\begin{array}{l}\text { Pulau } \\
\text { Mansinam }\end{array}$ & $\begin{array}{l}45.46 \pm 9.27 \\
97.23 \% \pm 1.23\end{array}$ & $\begin{array}{l}1.18 \pm 0.56 \\
2.42 \% \pm 0.71\end{array}$ & $\begin{array}{l}0.21 \pm 0.35 \\
0.35 \% \pm 0.61\end{array}$ & $53.14 \pm 10.60$ & $\begin{array}{l}\text { Pasir/ } \\
\text { Sedimen } \\
\text { Karbonat }\end{array}$ \\
\hline $\begin{array}{l}\text { Pulau } \\
\text { Lemon }\end{array}$ & $\begin{array}{l}65.33 \pm 12.17 \\
98.18 \% \pm 1.45\end{array}$ & $\begin{array}{l}1.34 \pm 1.32 \\
1.81 \% \pm 1.45\end{array}$ & $\begin{array}{l}0 \pm 0 \\
0 \% \pm 0\end{array}$ & $33.33 \pm 13.48$ & $\begin{array}{l}\text { Pasir/ } \\
\text { Sedimen } \\
\text { Karbonat }\end{array}$ \\
\hline
\end{tabular}

Ket: a data adalah rata-rata dari tiga ulangan \pm standart deviasi 
Hasil pengelompokkan ditemukan 2 tipe tekstur sedimen yaitu pasir untuk daerah outland (sedimen carbonat) sedangkan pasir berlempung untuk daerah mainland (sedimen terrigenous berasal dari daratan).

Distribusi ukuran partikel sedimen sangat mempengaruhi pertukaran air pori dengan kolom air di bagian atasnya. Distribusi ukuran partikel yang cenderung kearah debu dan liat akan menyebabkan pertukaran air pori dengan kolom air menjadi rendah (Huettel \& Gust 1992) sebaliknya kondisi akan dialami oleh makroalga jika menempati tipe sedimen pasir kasar, dimana pertukaran air pori dengan kolom air tinggi dengan arus yang membawa nutrien untuk pertumbuhan dan perkembangan alga.

\section{Analisis indeks struktur $\mathrm{K}=$ komunitas makroalga}

Indeks keanekaragaman ( $\left.H^{\prime}\right)$, keseragaman (E) dan dominansi (C)

Berdasarkan hasil analisis struktur komunitas yaitu keanekaragaman (H'), keseragaman (E) dan dominansi (D) pada 5 lokasi penelitian menunjukkan bahwa daerah mainland lokasi Arfai (stasiun 1) memiliki indeks keanekaragaman sebesar 2.56, indeks keseragaman sebesar 0.92 dan indeks dominansi sebesar 0.09 Sedangkan indeks keanekaragaman didapatkan di lokasi Rendani (stasiun 2) sebesar 2.50 indeks keseragaman sebesar 0.95 dan indeks dominansi sebesar 0.09. Lokasi Pasir Putih (stasiun 3), indeks keanekaragaman sebesar 2.54 indeks keseragaman sebesar 0.94 dan indeks dominansi sebesar 0.09 sedangkan untuk Lokasi outland pulau Mansinam (stasiun 4) indeks keanekaragaman sebesar 2.83 indeks keseragaman sebesar 0.93 dan indeks dominansi sebesar 0.07 dan lokasi pulau Lemon (stasiun 5) indeks keanekaragaman sebesar 2.80 indeks keseragaman sebesar 0.92 dan indeks dominansi sebesar 0.08. Analisis indeks keanekaragaman, keseragaman dan dominansi pada kelima lokasi penelitian di perairan Manokwari diuraikan pada (Tabel 10).

Indeks keanekaragaman suatu komunitas dapat menggambarkan tingkat kestabilannya. Nilai indeks ini dipengaruhi oleh jumlah individu setiap jenis makroalga dan jumlah total individu seluruh jenis makroalga. Indeks keanekaragaman pada 5 lokasi penelitian termasuk kategori sedang, yaitu kisaran indeks keanekaragaman lebih besar 1 lebih kecil 3 (Tabel 10). Walaupun demikian, diantara lima lokasi daerah outland lokasi Mansinam dan Lemon memiliki nilai lebih tinggi keanekaragamannya mendekati 3 dengan nilai indeks keanekaragaman Mansinam 2.83 dan Lemon 2.80 yang mengindikasikan perairan outland memiliki keanekaragaman yang tinggi, penyebaran jenis makroalga dan kestabilan komunitas yang tinggi hal ini disebabkan karena perairan jernih, tingkat kecerahan yang tinggi dengan tekstur substrat karbonat pasir potongan patahan karang yang dasar perairan sangat baik bagi pertumbuhan dan perkembangan makroalga (Aslan 1998). Daerah outland pulau Mansinam dan Lemon letaknya di Teluk bagian luar dengan kecepatan arus yang stabil yang memungkinkan penyebaran makroalga sangat besar sesuai dengan pendapat Handayani et al. (2007) dan Litaay (2014) dimana lokasi penelitian yang berada di Teluk terluar atau letaknya berada dekat laut lepas memiliki penyebaran makroalga yang sangat besar dengan indeks keanekaragaman yang tinggi dibandingkan dengan daerah mainland lokasi Arfai, lokasi Pasir Putih dan yang paling rendah Rendani (Gambar 4) dimana lokasi mainland dipengaruhi oleh sedimentasi yang tinggi, perairan keruh, dan masukan bahan organik dengan tipe substrat daerah mainland sedimen terrigenous berasal dari daratan dengan pusat aktivitas masyarakat pesisir di perkotaan seperti frekuensi transportasi perkapalan, kegiatan pelebaran bandara Rendani sangat mempengaruhi keanekaragaman jenis makroalga. Pernyataan ini didukung oleh Langoy et al. (2011) mengemukakan aktivitas masyarakat pesisir di perairan cenderung mempengaruhi keanekaragaman makroalga. Indeks keseragaman pada 5 lokasi penelitian daerah mainland dan outland mendekati 1 dimana populasi individu makroalga tiap jenis menyebar merata dan tidak ada makroalga yang dominan, sedangkan untuk indeks dominansi 5 lokasi penelitian mendekati 0 dimana komunitas makroalga penyusunnya berada dalam keadaan stabil (Gambar 4). 
Tabel 10. Nilai indeks keanekaragaman (H'), keseragaman (E) dan dominansi $(C)$ pada 5 lokasi penelitian

\begin{tabular}{lccc}
\hline \multicolumn{1}{c}{ Lokasi } & $\begin{array}{c}\text { Keanekaragaman } \\
\left(\mathrm{H}^{\prime}\right)\end{array}$ & $\begin{array}{c}\text { Keseragaman } \\
(\mathrm{E})\end{array}$ & $\begin{array}{c}\text { Dominansi } \\
(\mathrm{C})\end{array}$ \\
\hline Arfai & 2.56 & 0.92 & 0.09 \\
Rendani & 2.50 & 0.95 & 0.09 \\
Pasir Putih & 2.54 & 0.94 & 0.09 \\
Mansinam & 2.83 & 0.93 & 0.07 \\
Lemon & 2.80 & 0.92 & 0.08 \\
\hline
\end{tabular}

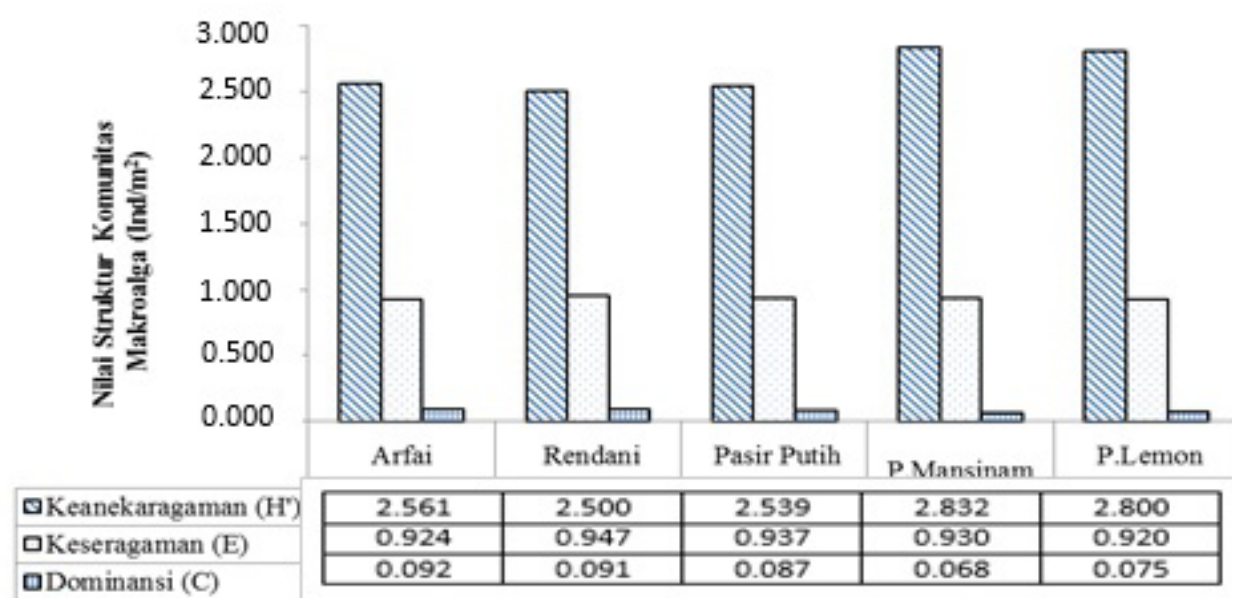

Gambar 4. Histogram indeks keanekaragaman (H'), indeks keseragaman (E) dan indeks dominansi (C) makroalga di 5 lokasi Penelitian

\section{KESIMPULAN}

Komposisi spesies makroalga ditemukan 28 spesies yang di klasifikasikan ke dalam 3 divisi, 3 kelas, 11 ordo, 16 famili, dan 19 genus yang di kelompokkan dalam 3 divisi utama yaitu alga hijau (Chlorophyta) 14 spesies, alga merah (Rhodophyta) 8 spesies dan alga coklat (Phaeophyta) 6 spesies. Total rata-rata kepadatan jenis makroalga di daerah outland lebih tinggi di bandingkan dengan daerah mainland. Nilai pengukuran parameter fisik-kimia umumnya masih berada pada kisaran normal, tetapi lokasi yang lebih baik di daerah outland dibandingkan dengan mainland. Analisis sedimen ditemukan 2 tipe tekstur sedimen yaitu pasir untuk daerah outland lokasi Mansinam dan Lemon sedimen (carbonat) sedangkan pasir berlempung untuk daerah mainland lokasi Arfai, Rendani dan Pasir Putih sedimen (terrigenous) berasal dari daratan.

Analisis strutur komunitas makroalga daerah outland memiliki indeks keanekaragaman lebih tinggi di bandingkan dengan daerah mainland. Indeks keseragaman pada 5 lokasi penelitian daerah mainland dan outland mendekati 1 dimana populasi individu makroalga tiap jenis menyebar merata dan tidak ada makroalga yang dominan, sedangkan untuk indeks dominansi mendekati nol dimana komunitas makroalga penyusunnya berada dalam keadaan stabil.

\section{DAFTAR PUSTAKA}

Aslan LM. 1998. Budidaya Rumput Laut. Penerbit Kanisius (Anggota IKAPI). Yogyakarta.

Atmadja WS, Kadi A, Sulistijo, Rachmaniar. 1996. Pengenalan Jenis-Jenis Rumput Laut Indonesia. Puslitbang Oseanologi LIPI. Jakarta.

Biro Pusat Statistik (BPS). 2014. Kabupaten Manokwari dalam Angka. Badan Pusat Statistik Kabupaten Manokwari. Papua Barat.

Bhavanath J, Reddy CRK, Thekur MC, Rao MU. 2009. Seaweed of India. The Diversity and Distribution of Seaweed of the Gujarat Coast. Development in Applied Phycology. Springer Science 
Busines Media. DOI 10.1007/978-90481-2488-6_1.

Bold S, Wynne MJ. 1985. Introduction to The Algae. Prentice Hall Inc. Englewood Clift JJ New Jersey. USA.

Boyd CE. 1988. Water Quality in Pond for Aquaculture. Agricultural Experiment Station Auburn University. USA

Brower EJ, Zar JH. 1977. Field and Laboratory Method for General Ecology. WMC. Brown Company Publisher Dubuque IOWA.

Calumpong H P, Menez E G. 1997. Field Guide to the Common Mangrove, Seagrasses, and Algae of the Philippines. Bookmark Inc Makati City. Philippines.

Chapman VJ, Chapman DJ. 1990. Alga. Penerjemah: Latief $\mathrm{R}$ A, editor. Kuala Lumpur (ID): Dewan Bahasa dan Pustaka Kementerian Pelajaran Malaysia. Kuala Lumpur.

Coppejans E, Leliaert F, Dargent O, Gunasekara R, De Clerck O. 2009. Sri Lankan Seaweeds-Methodologies and Field Guide to the Dominant Species. ABC Taxa. Volume 6.

Dawes JC. 1981. Marine Botany. A Wiley Intercience Publication John Wiley and Sons, Inc.United State of America. New York.

Eem LP. 2010. Macroalgae Identification and the Current Status of Marine Introduced Macroalgae. University of Malaya. Malaysia.

Eleftheriou A, McIntyre A. 2005. Method for the Study of Marine Benthos. Third edition. Published Blackwell Science Company ltd. USA.

English S, Wilkinson C, Baker V. 1997. Survey Manual For Tropical Marine Resources. 2nd Edition. Australia Institut of Marine Science. Townsville.

Erina Y. 2006. Keterkaitan antara Komposisi Perifiton pada Lamun Enhalus acoroides dengan Tipe Substrat Lumpur dan Pasir di Teluk Banten [Tesis] Bogor (ID): Institut Pertanian Bogor.

Guiry MD, Guiry GM. 2014. Algae Base. World-Wide Electronic Publication, National University of Ireland, Galway. [Internet] [diuduh 2014 Des 11]. Tersedia pada http://www.algabase. org.

Hutagalung HP. 1988. Pengaruh Suhu Terhadap Kehidupan Organisme Laut. Pewarta Oseana. LON-LIPI. Jakarta Vol 13: 153-163.

Hutagalung HP, Rozak A. 1997. Penentuan
Kadar Oksigen Terlarut. Di dalam: Hutagalung HP, Setiapermana D, Riyono HS. Editor. Metode Analisis Air Laut, Sedimen dan Biota. Buku 2. Jakarta (ID): Pusat Penelitian dan Pengembangan Oseanologi LIPI.

Krebs CJ. 1989. Ecology Methodology. Harper Collins Publishers. New York.

Krupek RA, Branco CCZ. 2012. Ecological Distribution of Stream Macroalgae in Different Spatial Scales using Taxonomic and Morphological Groups. Brazilian Journal of Botany. 35(3): 273-280.

Langoy MD, Saroyo, Dapas F, Katili DY, Hamsir SB. 2011. Deskripsi Alga Makro di Taman Alam Batuputih kota Bitung.Jurnal Ilmiah Sains. 11(2) : 219-224.

Lewmanomont K, Ogawa H. 1995. Common Seaweeds and Seagrass of Thailand. Faculty of Fisheris Kasetsart University. Printed Integrated Promotion Technology Co,.Ltd. ISBN 974-553-137-5.

Litaay C. 2014. Sebaran dan Keragaman Komunitas Makro algae di Perairan Teluk Ambon. Jurnal Ilmu dan Teknologi Kelautan Tropis. 6 (1) : 131142.

Lobban CS, Horrison P J. 1997. Seaweed Ecology and Physiology. Published in the United State of America by Cambridge University Press. New York.

Ludwig JA, Reynolds J F. 1988. Statistical Ecology: A Primer on Methods and Computing. A Willey Interscience Publication.

Luning K. 1990. Seaweeds: Their Environment, Biogeography and Ecophysiology. John Willey and Sons. New York.

Magruder WH, Hunt JW. 1979. Seaweeds of Hawaii, A Photographic Identification Guide. Oriental Publishing Company Honolulu. Hawaii.

Nybakken JW. 1992. Biologi Laut: Suatu Pendekatan Ekologis (Terjemahan Bangen D G, Koesoebiono dan Eidman H). PT. Gramedia Pustaka Utama. Jakarta.

Papalia S, Arfah H. 2013. Produktivitas Biomassa Makroalga di Perairan Pulau Ambalau, Kabupaten Buru Selatan. Jurnal Ilmu dan Teknologi Kelautan Tropis. 5 (2) : 465-477.

Sanusi HS, Putranto S. 2009. Kimia Laut dan Pencemaran. Proses Fisik Kimia dan Interaksinya dengan Lingkungan. Edisi Pertama. Penerbit Departemen 
Ilmu dan Teknologi Kelautan, FPIK IPB.

Silva PC, Basson PW, Moe RL. 1996. Catalog of the Benthic Marine Algae of the Indian Ocean. University of California Press.

Sjöö GL. 2010. Macroalga in Tropical Seascape - Regulating Factors and Fuction in the Coastal Ecosystem. Department of System Ecology Stockhlom University. Printed in Sweden by US-AB. Stockholm. ISBN 978-91-7447-188-5.

Soegiarto A, Sulistijo, Wanda SA. 2011. Rumput Laut (Algae). Manfaat, Potensi dan Usaha Budidayanya. Penerbit Lembaga Oseanologi Nasional (LONLIPI). Jakarta.

Trono GC. 1997. Field Guide and Atlas of the Seaweeds Resources of the Philippines. Marine Science Institut College of Science University of the Philippines, Bookmarks Inc. Diliman Quezon City.
Verbruggen H, De Clerck O, Kooistra WHCF, Coppejans E. 2005. Evolution and Phylogeography of Halimeda section Halimeda (Bryopsidales, Chlorophyta). Moleculer and Phylogenetik Evolution Journal Elsevier Inc. All rights reserved.37: 789-803. doi:10.1016/j. ympev.2005.06.015.

Verbruggen $\mathrm{H}$, Tyberghein L, Pauly $\mathrm{K}$, Vlaeminck C et al. 2009. Macroecologi meets Macroevolution: Evolutionary niche dynamics in the Seaweeds Halimeda. Research Paper Global Ecol. Biogeogr. 18: 393-405. DOI: 10.1111/J.1466-8238.2009.00463.x.

Wardoyo S. 1981. Pengelolaan Kualitas Air. Proyek Peningkatan Mutu Perguruan Tinggi. Bogor (ID): Institut Pertanian Bogor.

Wei TL, Chin W Y. 1983. Seaweeds of Singapore. Singapore University Press (National University of Singapore), Pte Ltd Kent Ridge Singapore 0511. ISBN 9971-69-075-6. 